This item was submitted to Loughborough's Research Repository by the author.

Items in Figshare are protected by copyright, with all rights reserved, unless otherwise indicated.

\title{
Recent developments in manufacturing emulsions and particulate products using membranes
}

PLEASE CITE THE PUBLISHED VERSION

http://dx.doi.org/10.1016/j.cis.2004.10.002

PUBLISHER

(C) Elsevier

VERSION

AM (Accepted Manuscript)

LICENCE

CC BY-NC-ND 4.0

\section{REPOSITORY RECORD}

Vladisavljevic, Goran T., and Richard A. Williams. 2012. "Recent Developments in Manufacturing Emulsions and Particulate Products Using Membranes". figshare. https://hdl.handle.net/2134/10552. 
This item was submitted to Loughborough's Institutional Repository (https://dspace.lboro.ac.uk/) by the author and is made available under the following Creative Commons Licence conditions.

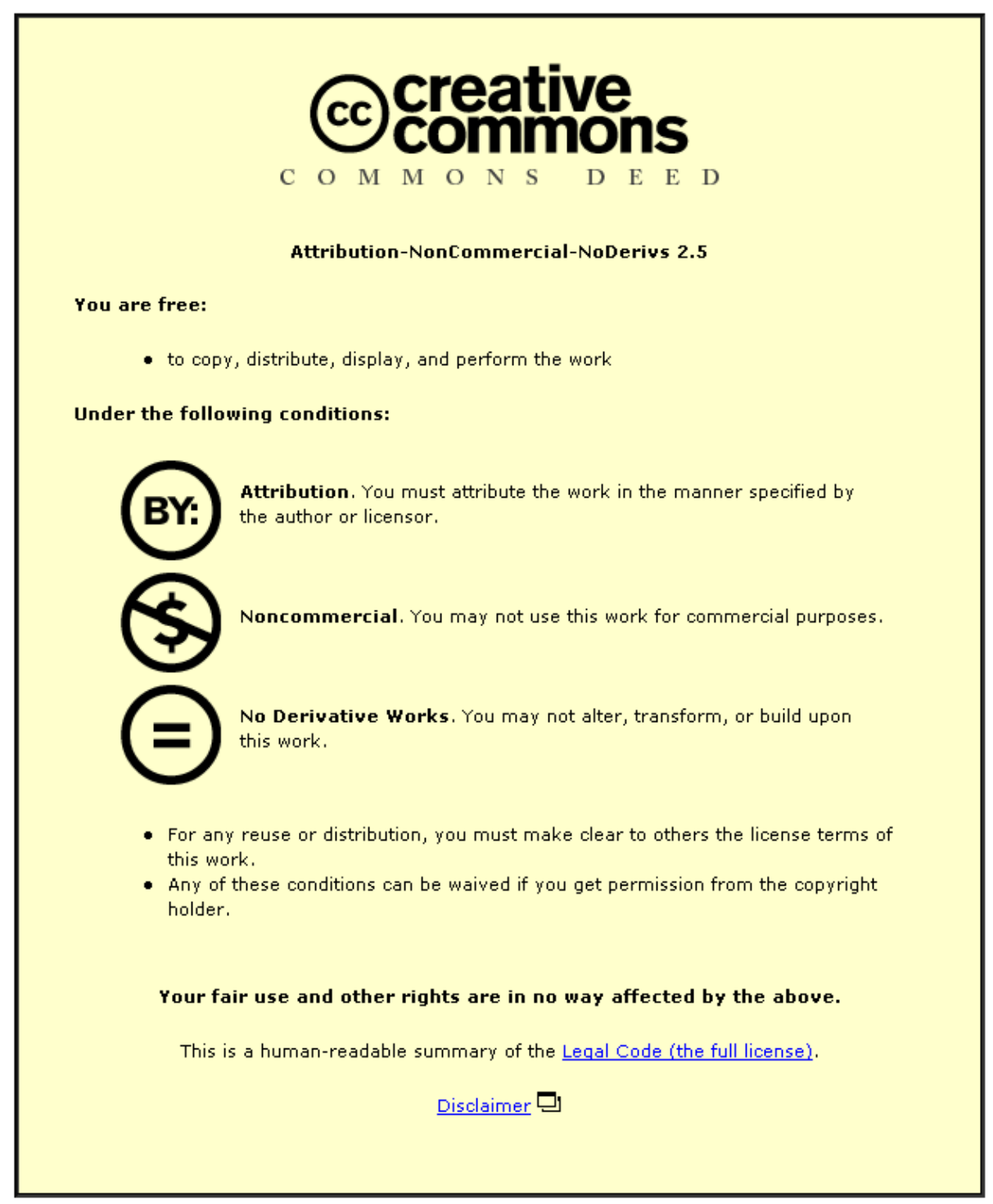

For the full text of this licence, please go to: http://creativecommons.org/licenses/by-nc-nd/2.5/ 


\section{Recent developments in manufacturing emulsions and particulate products using membranes}

Goran T. Vladisavljević ${ }^{1 *}$, Richard A. Williams ${ }^{2}$

${ }^{1}$ Institute of Food Technology and Biochemistry, Faculty of Agriculture, University of Belgrade, P.O. Box 127, YU-11081 Belgrade-Zemun, Serbia \& Montenegro.

Tel: (+381) 11615 315/327

Fax: (+381) 11199711

gtvladis@afrodita.rcub.bg.ac.yu

${ }^{2}$ Institute of Particle Science \& Engineering, School of Process, Environmental \& Materials Engineering, Clarendon Road, University of Leeds, Leeds, LS2 9JT, United Kingdom.

Tel: (+44) (0)113 343 2789/2801

Fax: (+44) (0)113 3432781

r.a.williams@leeds.ac.uk

*Corresponding author. 


\section{ABSTRACT}

Membrane emulsification is a relatively new technique for the highly controlled production of particulates. This review focuses on the recent developments in this area, ranging from the production of simple oil-in-water $(\mathrm{O} / \mathrm{W})$ or water-in-oil $(\mathrm{W} / \mathrm{O})$ emulsions to multiple emulsions of different types, solid-in-oil-in-water (S/O/W) dispersions, coherent solids (silica particles, solid lipid microspheres, solder metal powder), and structured solids (solid lipid microcarriers, gel microbeads, polymeric microspheres, core-shell microcapsules and hollow polymeric microparticles). Other emerging technologies that extend the capabilities into different membrane materials and operation methods (such as rotating membranes, repeated membrane extrusion of coarsely pre-emulsified feeds) are introduced. The results of experimental work carried out by cited researchers in the field together with those of the current authors are presented in a tabular form in a rigorous and systematic manner. These demonstrate a wide range of products that can be manufactured using different membrane approaches. Opportunities for creation of new and novel entities are highlighted for low throughput applications (medical diagnostics, healthcare) and for large scale productions (consumer and personal products).

Keywords: membrane emulsification; microchannel emulsification; microencapsulation; multiple emulsions; polymer microspheres. 


\section{Introduction}

The first investigation on using membrane emulsification can be traced back to the later 1980s when Nakashima and his colleagues [1] fabricated a particular glass membrane, called Shirasu Porous Glass (SPG), and successfully produced highly uniform-sized kerosene-in-water and water-in-kerosene emulsions [2-4]. Since this time the method has continued to attract attention due to its effectiveness in producing narrow droplet size distributions at low energy consumption. Although the majority of investigations on using membrane emulsification have been undertaken by Japanese workers, other novel research is being carried out in European countries [5-9]. To date, in addition to experimentation using SPG membranes, investigations of a broad range of other types of membranes, such as ceramic, metallic, polymeric and microengineered devices, have been reported (Table 1). The table indicates the form of the membrane, the nature of its surface, mean pore size and a typical effective membrane surface area deployed in the example cited in the table. Other types of porous materials can also be utilized such as silicon-based microfabricated channel devices with linear pores [29, 30] or microgrooves [31] on a single-crystal silicon chip and microfluidic devices of quartz glass [32] and PDMS [33]. The silicon-based channel devices with microgrooves and microfluidic devices are not considered in Table 1.

Table 2 illustrates the wide range of application areas of membrane and microchannel emulsification that have been developed from simple food spreads to complex colloidal assemblies manufacture. Examples of particulate products manufactured using membranes and microchannels are shown schematically in Figure 1. It can be seen that the methods afford the production of a variety of structure particulate materials by means of sequential 
secondary reactions/processes in the emulsified droplets, such as polymerisation, gelation, evaporation, freeze-drying, solidification, crystallization, droplet swelling, etc (Table 2). These processes can be used individually or in combination (e.g. evaporation or drying followed by crystallization or droplet swelling followed by polymerisation).

A general flowsheet for manufacture of particulate products via membrane emulsification routes is shown in Figure 2. Depending on the membrane hydrophilicity/hydrophobicity and the compositions of the two liquid phases, $\mathrm{O} / \mathrm{W}, \mathrm{W} / \mathrm{O}$ or $\mathrm{M} / \mathrm{W}$ emulsions may be produced. The single emulsion can be subjected to secondary emulsification to form a multiple emulsion or may undergo a process/reaction converting the droplets into solid particles or the continuous liquid phase into a solid phase. For example, non-aqueous droplets can be converted to polymer microspheres by heat-induced polymerisation (if they contain a monomer mixture) or by solvent evaporation (if they are composed of a preformed polymer dissolved in a volatile solvent). The oil droplets can be made up of a high melting-point oil and can be transformed into solid particles by cooling. Similarly, the hot droplets of a metal solder can be solidified to produce fine solder powder. The aqueous droplets can also be subjected to a number of solidification processes, depending on their formulation, such as gelation, polymerisation, crystallization, heat coagulation, etc.

It has been stated that the development of emulsification methods must be rooted in one of two possible manufacturing approaches [76]: (a) reduction of process length scales of the turbulent perturbations and enhancement of their uniformity in the mixing processes that rupture the liquids, and (b) manufacture of droplets individually (drop-by-drop) using micro-engineered structured systems. Membrane and microchannel emulsification, in 
which the production of emulsions is achieved by the droplets extruding from the outlet of many individual pores or microchannels, represents a typical example of the second approach. This paper aims to introduce the latest development on the utilisation of the membrane emulsification technique following on from some of our earlier investigations on using this technique for manufacture of emulsion dispersions. The physical principles of the process will be discussed in detail. Experimental work carried out by the authors and other researchers on exploring the boundaries of this unique technique will be reviewed.

The dispersity of the droplets throughout this paper will be expressed in terms of the coefficient of variation (relative standard deviation) or the relative span factor. For a specific size distribution the coefficient of variation is defined as $C V=\left(\sigma / \mathrm{d}_{\mathrm{av}}\right) \times 100$, where $\sigma$ is the standard deviation of the droplet diameters and $d_{a v}$ is the number-average mean droplet diameter. The relative span factor (or span) is defined as $\left(\mathrm{d}_{90}-\mathrm{d}_{10}\right) / \mathrm{d}_{50}$, where $\mathrm{d}_{\mathrm{x} 0}$ is the diameter corresponding to $\mathrm{x} 0$ vol. \% on a relative cumulative droplet diameter distribution curve.

\section{Principles and Process Systems for Membrane Emulsification}

Membrane emulsification (ME) methods reported so far in the literature are depicted schematically in Fig. 3. In conventional direct ME (Fig. 3 (a)), fine droplets are formed in situ at the membrane/continuous phase interface by pressing a pure disperse phase through the membrane. In order to ensure a regular droplet detachment from the pore outlets, shear stress is generated at the membrane/continuous phase interface by recirculating the continuous phase using a low shear pump (Fig. 4 (a)) [2] or by agitation in a stirring vessel 
[77] (Fig. 4 (b)). The rate of mixing should be high enough to provide the required tangential shear on the membrane surface, but not too excessive to induce further droplet break up. Another approach uses systems equipped with a moving membrane, in which the droplet detachment from the pore outlets is stimulated by rotation [16] or vibration [78] of the membrane within a stationary continuous phase (Fig 4 (c)). Even in the absence of any tangential shear, droplets can be spontaneously detached from the pore outlets at small disperse phase fluxes (Fig. 4 (d)), particularly in the presence of fast-adsorbing emulsifiers in the continuous phase and for a pronounced non-circular cross section of the pores [30]. This type of behaviour is similar to the interfacial tension driven-droplet formation process observed in grooved microchannel (MC) emulsification [79].

A potential disadvantage of direct ME is the relatively low maximum disperse phase flux through the membrane of typically $0.01-0.1 \mathrm{~m}^{3} /\left(\mathrm{m}^{2} \mathrm{~h}\right)$, that has to be restrained to avoid the transition from a 'size-stable' to 'continuous outflow' zone [30] and to avoid the steric hindrance among droplets that may be formed simultaneously at the adjacent pores [7]. It is observed that the formation of uniform droplets is only possible within the size-stable zone, in which the mean droplet size is almost independent on the disperse phase flux and wall shear stress [80]. In the ME studies with a microsieve [7] and SPG membranes [81] the disperse phase flux was $2.5 \mathrm{~m}^{3} /\left(\mathrm{m}^{2} \mathrm{~h}\right)$, but polydisperse droplets were obtained. Due to the low productivity, i.e. long production times, direct $\mathrm{ME}$ is more suitable for the preparation of relatively diluted emulsions with disperse phase contents up to 30 vol. \%. Nevertheless, this process enables to obtain very narrow droplet size distributions to be produced over a wide range of mean droplet sizes. In the case of SPG emulsification [8286], the mean droplet size of both $\mathrm{O} / \mathrm{W}$ and $\mathrm{W} / \mathrm{O}$ emulsions can range from less than $1 \mu \mathrm{m}$ 
to over $60 \mu \mathrm{m}$, with the relative span factors under optimal conditions of $0.26-0.45$. For ceramic membranes the droplet size range can be $0.2-100 \mu \mathrm{m}$ with a range of spans [87].

Suzuki et al. [88] implemented 'premix' ME, in which a preliminarily emulsified coarse emulsion (rather than a single pure disperse phase) is forced through the membrane (Fig. 3 (b)). This is achieved by mixing the two immiscible liquids together first using a conventional stirrer mixer, and then passing this preliminarily emulsified emulsion through the membrane. If the disperse phase of feed emulsion wets the membrane wall and suitable surfactants are dissolved in both liquid phases, the process may result in a phase inversion, i.e. a coarse $\mathrm{O} / \mathrm{W}$ emulsion may be inverted into a fine W/O emulsion (Fig. 3 (c)) and vice versa [20]. The main advantage of this method is that a fine emulsion can be easily prepared from a low concentration coarse emulsion at high rates. For a PTFE membrane used by Suzuki et al. [20], the maximum disperse phase content in the phase-inverted emulsions was 0.9 and 0.84 for $\mathrm{O} / \mathrm{W}$ and $\mathrm{W} / \mathrm{O}$ emulsions, respectively. Flow-induced phase-inversion (FIPI) phenomenon was investigated earlier by Akay [89] using a multiple expansion-contraction static mixer (MECSM), which is a series of short capillaries with flow dividers, and by Kawashima et al. [90] using hydrophobic polycarbonate membranes with a mean pore size of 3 and $8 \mu \mathrm{m}$. Kawashima et al. [90, 91] inverted a W/O/W emulsion consisting of liquid paraffin, Span 80 and Tween 20 into a semisolid W/O emulsion. This W/O emulsion was redispersed into an aqueous solution of hydrophilic surfactant to form W/O/W emulsion containing smaller and more uniform internal droplets than the original $\mathrm{W} / \mathrm{O} / \mathrm{W}$ emulsion. 
Premix ME holds several advantages over 'direct' ME: the optimal transmembrane fluxes with regard to droplet size uniformity are typically above $1 \mathrm{~m}^{3} /\left(\mathrm{m}^{2} \mathrm{~h}\right)$, which is $1-2$ orders of magnitude higher than in direct ME; the mean droplet sizes that can be achieved using the same membrane and phase compositions are smaller than in direct ME, which can be advantageous; the experimental set-up is generally simpler than in direct ME, e.g. no moving parts such as cross-flow pump or stirrer are needed, except for the preparation of pre-emulsion, and finally; the premix ME process is easier to control and operate than direct ME, since the driving pressure and emulsifier properties are not so critical for the successful operation as in the direct ME process.

In the first premix ME study [88] a cross-flow system was used, in which the coarse emulsion was diluted by permeation into pure continuous phase/diluted emulsion recirculating at the low-pressure side of the membrane. In the subsequent works (Table 3), a dead-end system was used, in which the fine emulsion was withdrawn as a product after passing through the membrane, without any recirculation and/or dilution with the continuous phase. It enables fast preparation of emulsions with a disperse phase content of 50 vol. \% or more [92]. One of the disadvantages of premix ME is a higher droplet polydispersity compared to direct ME. In order to combine the advantages of both techniques, i.e. high throughput of premix ME and narrow droplet size distribution of direct ME, a multi-pass (repeated) premix ME was attempted [21-22, 27, 92]. In this process, the fine emulsion is repeatedly passed through the same membrane a number of times to achieve additional droplet size reduction and enhance size uniformity (Table 3).

\section{Particle Manufacture}


There have been a few review papers available in the literature, describing various novel techniques for making emulsions and particulates. Williams [76] listed some of the engineering and technological challenges which could be facing researchers in manufacturing "designer particles" in large quantities. For example, for droplets between 10-100 $\mu \mathrm{m}$ microchannel (MC) emulsification process has, in particular, been considered an effective method of producing uniform particles, with typical coefficients of variation of $5 \%$ (this compares with normal CVs of about $10 \%$ for other membranes). The current state of membrane emulsification technology and the underlying process phenomena have been reviewed by several authors [93-96]. These articles are mainly focused on the influence of process parameters and membrane properties on the droplet size distribution and the transmembrane flux. Until now, however, a broad range of particulate products that can be produced by utilising this technique have not been presented in a systematic manner.

\subsection{Single emulsion production}

Single emulsion production by direct method is still the most investigated system for membrane emulsification applications. Table 4 lists some of the case studies recently reported in the literature. To allow continuous and optimal production of monodispersed emulsions, the affinities between the membrane surface, disperse and continuous phases and the electrical charge on the functional groups of emulsifiers must be considered carefully. For a preparation of O/W emulsions, hydrophilic membranes must be used. This avoids the wetting and spreading of the disperse phase (i.e., oil) on the membrane surface. Similar principles may also apply to the choice of the emulsifiers. The functional groups of 
the chosen emulsifiers must not carry the charge opposite to that of the membrane surface in order to facilitate the membrane surface retaining its hydrophilicity. For example, an untreated SPG membrane has a negative surface potential of -15 to $-35 \mathrm{mV}$ within the $\mathrm{pH}$ range of 2 to 8, due to the dissociation of acid silanol groups [101]. Hence for the above $\mathrm{O} / \mathrm{W}$ case, use of cationic emulsifiers such as CTMABr or TOMAC must be avoided. The same conclusion holds for emulsification using silicon MCs [30].

For a preparation of W/O emulsions, hydrophobic membranes and MCs must be used. The SPG membrane and silicon MCs are inherently hydrophilic. Hydrophobic treatment of SPG membranes can be successfully carried out by coating the membrane surface with a silicone resin. It was recently shown that even in the submicron range of mean pore sizes the membrane resistance was unaffected by this treatment, which means that the pores were not plugged by the resin [102]. However care does has to be taken in this silinisation process to avoid blockages.

\subsection{Production of multiple (complex) emulsions}

Production of so-called multiple emulsion involves the preliminary emulsification of two phases (e.g., W/O, O/W or E/O), followed by secondary emulsification into a third phase leading to a three phase mixture, such as $\mathrm{W} / \mathrm{O} / \mathrm{W}, \mathrm{O} / \mathrm{W} / \mathrm{O}$ or $\mathrm{E} / \mathrm{O} / \mathrm{W}$. The primary emulsion is usually prepared under intense homogenisation conditions to obtain as fine internal droplets as possible. The secondary emulsification step is carried out under less severe conditions in order to avoid rupture of the liquid membrane between the internal disperse phase and continuous phase of the multiple emulsion. If the second step is carried out using a conventional emulsification device, the external droplets are in most cases 
highly polydisperse or the entrapment efficiency is very small. Membrane or MC emulsification enables to obtain narrow size distribution of the external droplets, and yet to maintain a high encapsulation yield of the internal droplets [49].

\subsubsection{Water-in-oil-in-water emulsions}

The W/O/W type of emulsions is particularly important to the pharmaceutical industry to initiate contained and targeted drug delivery [35]. The W/O/W emulsions were prepared in two steps. A submicron W/O emulsion was first prepared using a hydrophobic membrane or conventional rotor stator emulsification device. The water phase contained an anticancer drug (epirubicin), and the oil phase was made up of an iodised poppy seed oil (Lipiodol) with polyoxyethylene (40) hydrogenated caster oil being used as the hydrophobic surfactant. This was then followed by further emulsification using a hydrophilic membrane and the W/O emulsion as the disperse phase. Clinical trials showed that the multiple drug emulsion, when administered directly into the liver via the hepatic artery, was effective in contracting the liver cancer texture. It was concluded that ME enabled the design of a controlled release vehicle at a much higher production yield in comparison with other traditional methods. Mine et al.'s study [103] revealed that to make a stable W/O/W emulsion, the concentration of internal water droplets must be between 30 and $50 \%(\mathrm{v} / \mathrm{v})$, and the membrane pore size for the second step emulsification must be no less than twice the diameter of the internal droplets.

Multiple emulsions can also be produced using a MC plate in much the same way as that done using a porous membrane. Kawakatsu et al. [40] and Sugiura et al. [104] investigated production of $\mathrm{W} / \mathrm{O} / \mathrm{W}$ emulsions by $\mathrm{MC}$ emulsification. The emulsions were prepared by 
first homogenising a mixture of water and oil phase using a conventional homogeniser. The W/O emulsion thus obtained was then forced through the MC device into a second water phase containing a suitable emulsifier for oil phase stabilisation. The monodispersed droplets of W/O emulsion were prepared using 5 wt. \% tetraglycerine polyricinolate dissolved in MCT, decane or ethyl oleate as the oil phase [104]. The oil film between the two water phases was not broken when the internal droplets larger than the MCs penetrated through the channels. The internal water droplets larger than the resulting W/O/W droplets were divided into several smaller droplets before being penetrated through the channels. The low shear stress conditions during secondary emulsification led to a high entrapment efficiency estimated to be of $91 \%$.

\subsubsection{Oil-in-water-in-oil emulsions and spreads}

Okonogi et al. [38] developed a method for producing a O/W/O type edible emulsion, which involved dispersing an $\mathrm{O} / \mathrm{W}$ emulsion into a fatty phase through a hydrophilic microporous glass membrane which has been rendered hydrophobic by the pre-immersion into the fatty phase. An O/W/O type spread can be manufactured by rapidly cooling and kneading the $\mathrm{O} / \mathrm{W} / \mathrm{O}$ emulsion consisting primarily of plastic oils, aqueous solution, and emulsifiers. The fatty phase constituents preferably 25 to $75 \%$ of the final product, and the external oil phase preferably $20 \%$ and more of the total fatty phase. The authors suggested that using membrane emulsification technology for the production of W/O type low-fat spread and O/W/O type spread, it was possible to reduce the amount of fatty phase in the whole compositions to $20 \%$ for the W/O type spread and $25 \%$ for the O/W/O type spread in comparison with other traditional methods, without using stabilizers and gelling agents 
as essential ingredients. To date these methods have not been widely implemented on an industrial scale.

\subsubsection{Ethanol-in-oil-in-water emulsions}

Nakajima et al. [39] patented functional emulsions for use in food, drugs and cosmetics, consisting of ethanol as a disperse phase and oil as a continuous phase $(\mathrm{E} / \mathrm{O})$ or ethanol-inoil emulsion as a disperse phase and water as a continuous phase $(\mathrm{E} / \mathrm{O} / \mathrm{W})$. An ingredient which is insoluble or having a low solubility in water and oil (e.g. polyphenols, taxol, androstenedione, validamycin, etc) is dissolved in ethanol at the concentration of $20-30 \%$ and the ethanol solution is then dispersed into oil phase using a conventional homogeniser or membrane/MC emulsification. The E/O emulsion can be further dispersed into water phase to produce E/O/W multiple emulsions with a wide range of applications as emulsion delivery systems in food, drugs and cosmetics.

\subsection{Production of solid-in-oil-in-water dispersions}

Toorisaka et al. [41] prepared a S/O/W dispersion for oral administration of insulin by passing a preliminary emulsified $\mathrm{S} / \mathrm{O} / \mathrm{W}$ dispersion several times (usually three) through a SPG membrane with a mean pore size of $1.1 \mu \mathrm{m}$. The $\mathrm{S} / \mathrm{O}$ suspension containing surfactant-coated insulin dispersed in soybean oil was first mixed with aqueous solution containing a hydrophilic surfactant (sugar ester L-1695), sodium cholate and d-glucose to prepare a coarse $\mathrm{S} / \mathrm{O} / \mathrm{W}$ dispersion using a conventional rotor stator homogeniser. The coarse S/O/W dispersion was then homogenised by passing through the SPG membrane to prepare a monodispersed emulsion with the mean droplet size of $1.0 \mu \mathrm{m}$. The surfactant- 
coated insulin was prepared by mixing an aqueous solution of insulin with a hexane solution containing a lipophilic surfactant (sugar ester ER-290), followed by freeze-drying. The S/O/W dispersion showed the hypoglycemic activity for a long period after oral administration to rats, owing to the conversion of insulin into a lipophilic complex and uniform droplets of S/O suspension [41].

Supsakulchai et al. [67] prepared S/O/W dispersions by extruding S/O suspensions containing fine particles of anatase-type titanium dioxide in poly(St-co-AA)-toluene solutions through the SPG membrane into an aqueous phase containing dissolved PVA and SDS. The polymer microcapsules containing $10-20$ wt. $\%$ of $\mathrm{TiO}_{2}$ were prepared from the S/O/W emulsions by vacuum evaporation of toluene. In this study, the SPG membrane emulsification process failed to yield uniform capsules due to some wetting problems.

Kawakatsu et al. [40] investigated the preparation of S/O/W pectin microcapsules by MC emulsification. The microcapsules were prepared by first homogenising a water phase $(0.5$ wt. \% pectin solution) and oil phase (3 wt. \% TGCR in oleic acid) using a conventional homogeniser. The W/O emulsion was then forced through a MC plate into the second water phase containing $\mathrm{CaCl}_{2}$ and Tween 20. The W/O/W emulsion was converted into a $\mathrm{S} / \mathrm{O} / \mathrm{W}$ dispersion by gelation of the internal water droplets due to interfacial reaction between pectin macromolecules and calcium ions.

\subsection{Production of coherent solids}

\subsubsection{Silica micro- and nanoparticles}


Silica micro- and nanoparticles find numerous uses as catalysts, coatings, stiffeners, binders, polishing agents for silicon wafers, absorbents, thickeners, reinforcing agents in organic polymers, etc. Kandori et al. [43] prepared silica microparticles by first adjusting the $\mathrm{pH}$ of a sodium silicate solution to 2.0 with $2.3 \mathrm{M}$ sulphuric acid and then extruding the acidic sodium silicate solution through the SPG membrane into 2-10 wt. \% solution of PE64 surfactant in toluene. To avoid polymerisation of silicic acids before emulsification, the acidic sodium silicate solution was prepared just prior to its use. The obtained sodium silicate droplets were converted into silica hydrogel particles by gently mixing the W/O emulsion for 7 days at room temperature. Using the SPG membranes with a mean pore size of 0.98 and $2.7 \mu \mathrm{m}$, the silica hydrogel particles with a mean size of $0.9-1.3 \mu \mathrm{m}$ were prepared, which was $63-86 \%$ of the mean droplet size in the W/O emulsion before polymerisation. Yanagishita et al. [13] prepared silica nanoparticles using an anodic porous alumina membrane with uniform pores of $125 \mathrm{~nm}$ diameter. $1 \mathrm{M}$ aqueous sodium silicate solution was forced through the hydrophobic membrane into a mixture of hexane and cyclohexane containing 2.5 wt. \% Tween 85 . The resultant W/O emulsion was added to an aqueous ammonium carbonate solution and the mixture was agitated at $40{ }^{\circ} \mathrm{C}$ for 8 hours to solidify the sodium silicate droplets by interfacial polymerisation of silicic acids. The mean size of the silica particles was $70 \mathrm{~nm}$ and the CV was $26 \%$.

\subsubsection{Metal solder particles}

Uniform solder microparticles are increasingly in demand for surface mount technology in the electronics industry. This is a method of assembling printed circuit boards where the components are mounted onto the surface of the board rather than being inserted into holes in the board. Shimizu et al. [42] manufactured solder microparticles by a temperature- 
controlled SPG membrane emulsification at 80-200 ${ }^{\circ} \mathrm{C}$. Liquid solder metal was dispersed into an aqueous solution of SDS using a hydrophilic SPG membrane to form a metal-inwater (M/W) emulsion. Alternatively, hot liquid metal was extruded through a hydrophobic SPG membrane into an organic phase composed of TGCR, lead stearate or stearic acid dissolved in kerosene, paraffin or toluene. Fine solder particles were obtained by quenching the resulting $\mathrm{M} / \mathrm{W}$ or $\mathrm{M} / \mathrm{O}$ emulsion.

\subsubsection{Solid lipid microspheres}

Production of solid lipid microspheres by MC emulsification was investigated by Sugiura et al. [44] and Kobayashi et al. [45]. In Sugiura et al.'s study, microspheres were produced by a temperature-controlled MC emulsification process and subsequent solidification of the whole disperse phase (a high melting point edible oil), while in Kobayashi et al.'s study, lipid microparticles were produced by solvent evaporation method. In the former case, tripalmitin or hydrogenated fish oil with the melting points of $58{ }^{\circ} \mathrm{C}$ penetrated through the MCs into an aqueous solution of emulsifier at $70{ }^{\circ} \mathrm{C}$ and an $\mathrm{O} / \mathrm{W}$ emulsion with an average droplet diameter of $21 \mu \mathrm{m}$ and the CV of $4 \%$ was obtained. Solid lipid microspheres with the same size and uniformity were formed by cooling and freeze-drying of the $\mathrm{O} / \mathrm{W}$ emulsion. In the study of Kobayashi et al. [45], the oil phase (0.1-1 vol. \% tripalmitin dissolved in hexane) was dispersed into the continuous water phase (1 wt. \% SDS or pentaglycerol monolaurate) by MC emulsification at room temperature. The average diameter of oil droplets was 10-11 $\mu \mathrm{m}$ and the CV was below $8 \%$. Solid microspheres with an average diameter of $1-3 \mu \mathrm{m}$ and the CV of $20 \%$ were produced by evaporation of organic solvent under atmospheric pressure and room temperature for $24 \mathrm{~h}$. The volume ratio of oil droplets with respect to solid microspheres corresponded well to the volume 
ratio of the whole oil phase with respect to tripalmitin. It should be noted here that solvent evaporation method enables to obtain smaller, but less monodispersed lipid microspheres.

\subsubsection{Crystal products}

Membrane processes can be used to formulate crystal products as described elsewhere [4647]. A variety of systems have been used based on using the membrane as a microdisperser for two miscible aqueous phases and some using emulsified droplets as the microreactors that subsequently produce crystals as a result of changes in the chemical environment within the droplets. The latter process will be considered here as it is mediated by an emulsion phase. This type of process is suited to rate processes that are quite slow and as such can be regarded as two-stage processes, consisting of droplet formation in $\mathrm{ME}$ followed by crystal nucleation and growth. Work has been reported on different chemical systems [47] using cross flow membrane emulsification and is often referred to as XMC. A detailed study of the crystallization of hexadecyl palmitate has been reported in which 160 nm crystals were obtained using an alumina ceramic membrane ( $0.5 \mu \mathrm{m}$ pore size). The ester was dissolved in toluene and mixed with water and Tween 20, with the level of ester being controllable. An emulsion was formed via ME and the resultant droplets (whose size could be controlled) were then allowed to shrink as the toluene evaporated. Judicious selection of the initial ester concentration in the droplet and the size of the droplet was used to determine the final crystallite size. Fig. 5 shows some micrographs taken at different times during such a re-crystallization process and illustrates the evolution of a crystal. Here the timescales are set by the rate of evaporation of the solvent and proper design of XMC may allow this to be deployed as a specialist manufacturing route for precision crystallization. 


\subsection{Production of solid lipid microcarriers}

Nakashima [37] have reported production of three kinds of solid lipid microcarriers using SPG membranes. These microcarriers were particularly investigated for oral administration of irinotecan hydrochloride (CPT-11), which is a highly effective anticancer drug with unfavorable side effects. A preparation flowsheet of the so-called solid microcarrier and water-in-oil (W/O) carrier is similar (Figure 6). A submicron W/O emulsion containing more than $50 \mathrm{mg} / \mathrm{l} \mathrm{CPT-11}$ in aqueous solution as a disperse phase and $10 \mathrm{wt}$. \% TGCR in tripalmitin as a continuous phase was first prepared using a conventional rotor stator emulsification device at $80{ }^{\circ} \mathrm{C}$ to prevent oil solidification. This was then followed by dispersion of the $\mathrm{W} / \mathrm{O}$ emulsion in an external water phase at $80^{\circ} \mathrm{C}$ by a stirrer. The coarse polydispersed W/O/W emulsion was homogenised by passing through the SPG membrane with a mean pore size of about $11 \mu \mathrm{m}$. The W/O microcarrier was obtained by cooling the W/O/W emulsion and subsequent filtration of the solidified emulsion. Figure 7 shows a SEM photograph of the solidified W/O particle. The estimated entrapment efficiency of CPT-11 in the W/O carrier was more than $90 \%$ under optimal conditions [105].

A W/O carrier for the taste improvement of raw miso paste containing droplets of an aqueous solution of 5'-ribonucleotide embedded in the hardened palm oil was produced in the similar way [37]. The solid microcarrier containing a solid drug or nutrient within a porous solid lipid particle was obtained by freeze-drying of the W/O/W emulsion. The production of solid-in-oil $(\mathrm{S} / \mathrm{O})$ microcarrier involves freeze-drying of the $\mathrm{S} / \mathrm{O} / \mathrm{W}$ emulsion, as shown in Figure 6. 


\subsection{Production of gel microbeads}

Alginate beads have been extensively used in microencapsulation because they are very easy to prepare on a lab-scale, the process is very mild and virtually any ingredient can be encapsulated [106]. However, as easy as it to make small batch using a syringe extruder and a stirred calcium bath, the scaling up of the process is very difficult and processing costs are stupendous. Weiss et al. [50] developed a ME-based process in which an aqueous Na-alginate solution was extruded through a hydrophobic SPG membrane into a nonaqueous phase (2-5 \% Span 80 in MCT oil) to form a W/O emulsion. The droplets were crosslinked by adding $3 \% \mathrm{CaCl}_{2}$ solution and the microbeads were collected by filtration. The process can easily be scaled up and allow formation of uniform microbeads with an adjustable mean size (20-300 $\mu \mathrm{m})$, which is difficult to achieve using conventional alginate beads processes. Liu et al. [17] produced Ca-alginate beads with a mean size of about 55 $\mu \mathrm{m}$ and the CV of $27 \%$ using a nickel membrane with a mean pore size of $2.9 \mu \mathrm{m}$. A W/O emulsion containing $25 \mathrm{mM} \mathrm{CaCO}_{3}$ in $0.5-2 \% \mathrm{w} / \mathrm{v}$ Na-alginate solution as a disperse phase and $1.5 \% \mathrm{v} / \mathrm{v}$ Span 80 in paraffin oil as a continuous phase was prepared using the Ni membrane, pretreated by soaking in paraffin oil for at least 8 h. The gelation was initiated by the addition of glacial acetic acid into the emulsion, dissolving $\mathrm{CaCO}_{3}$ to release $\mathrm{Ca}^{2+}$. Iwamoto et al. [48] produced gelatin microbeads with a mean size of about 32 $\mu \mathrm{m}$ and the $\mathrm{CV}$ of $7.3 \%$ by MC emulsification. A W/O emulsion containing 5 wt. \% gelatin in water as a disperse phase and $5 \mathrm{wt}$. \% TGCR in IO as a continuous phase was prepared at $40{ }^{\circ} \mathrm{C}$ using hydrophobic MCs pretreated with octadecyltrichlorosilane. The 
gelation was induced by decreasing temperature of the emulsion to $25{ }^{\circ} \mathrm{C}$. After a slow gelation at $25^{\circ} \mathrm{C}$ overnight, the solidification of droplets was completed at $5{ }^{\circ} \mathrm{C}$.

\subsection{Production of albumin microspheres}

Albumin microspheres (AMS) have found many applications in the medical diagnosis and treatment in recent years. Monodisperse AMS were prepared by both chemical and thermal hardening methods via membrane emulsification [51-53]. A monodisperse W/O emulsion was first prepared by passing albumin solution through a hydrophobic SPG membrane into kerosene. After heating the emulsion, monodisperse AMS were prepared and the heatdenaturing process itself did not affect their monodispersity once uniform droplets had been prepared. The shape and size of the albumin microspheres strongly depended on the concentration of the albumin solution and the heat denaturing temperature.

\subsection{Production of polymer microspheres}

The production of monodisperse polymer microspheres with the mean diameter of 1-40 $\mu \mathrm{m}$ is becoming increasingly important as these spheres are used in many sophisticated applications, because of their large surface-to-volume ratio and functionality. Uniform polymer microspheres, hydrophilic and hydrophobic, smooth and rough, solid and hollow, porous and uniform, with different morphologies (spherical, hemispherical, snowman-like, popcorn-like, etc) with diameters ranging from several micrometers to $100 \mu \mathrm{m}$, were successfully produced using SPG membrane emulsification [75, 107, 108]. These spheres were investigated for use as packing materials for column chromatography techniques such 
as gel permeation chromatography (GPC) [109], high-performance liquid chromatography (HPLC) [110, 111], capillary electrochromatography (CEC) [111], and size-exclusion chromatography [112], pH sensors [113], carriers of enzymes (glucoamylase) [114], drug delivery systems [65], dry and liquid toners for electrophotography [115, 116, 78], spacers for liquid crystal displays (LCDs) and adhesives or insulators for micro-tip circuits [117, 118]. Fig. 8 shows PDVB spacers for LCDs, manufactured by Sekisui Chemical Industries Co. Ltd. using a SPG membrane emulsification technique [34].

Figure 9 shows an example of manufacture of quite large polymer beads (in the size range 80-500 $\mu \mathrm{m})$ manufactured using an interfacial polymerisation method [15, 51]. In this case the membrane used was stainless steel perforated with approximately circular pores of 140 microns in diameter. The membrane was configured as a cylinder and rotated to create a so-called spinning membrane reactor $[16,49]$. In this case there was relatively poor control of the beads but the principle of making such beads using a rotating membrane and with using continual recirculation of the dispersed phase (see Figure 4(c)) was achieved.

\subsubsection{One-stage (direct) suspension polymerisation}

In one-stage polymerisation process, an oil phase containing a monomer or a mixture of monomers, an initiator (BPO, AIBN or ADVN), and other potential additives (solvents, diluents, crosslinking agents, etc) permeates through the membrane into an aqueous solution of emulsifiers and stabilisers to form uniform droplets (O/W emulsion). An inhibitor such as $\mathrm{NaNO}_{2}$, DAP or HQ is dissolved in the aqueous phase to prevent the secondary nucleation of polymer particles in the aqueous phase. The suspension polymerisation is then carried out by transferring the emulsion into a reactor and heating it 
to above the decomposition temperature of the initiator under mild agitation and nitrogen bubbling. The initial narrow droplet size distribution can be retained throughout the polymerization stage, if the polymerisation conditions are adequate. A broad range of polymer microspheres with the CV of about $10 \%$ were produced by this method using SPG membrane (Table 5). Although a further classification is needed to obtain particles with the $\mathrm{CV}$ value of $4 \%$, which is a minimum requirement for LCD spacers, the classification step is less complicated and cheaper than for microspheres with a broad size distribution prepared by a conventional suspension polymerisation [117].

The polymer beads may be made porous by the inclusion of crosslinking agents (DVB for PSt and EGDMA for PMMA) and adequate diluents (poor solvents for the base polymer constituting a network) in the oil phase. The diluents (alkanes, middle-chain alcohols, etc) stimulate a micro-phase separation during polymerisation, resulting in the formation of a porous structure. Trifunctional crosslinker TMPTMA was included in the monomer phase to improve the compressive strength of the particles by increasing the crosslink density, so that the microspheres could be used as spacers for LCDs [117]. Acrylic acid was added to incorporate carboxyl groups to immobilize enzymes, and GMA was used to introduce spacer arms [114]. Colouring and charge control agents were incorporated in the monomer phase to prepare toner particles with the desirable coloring and triboelectric discharging properties [78]. $\mathrm{TiO}_{2}$ fine particles may also be included as fluorescent whitening agents to improve whiteness, brightness, and opacity of the microspheres [122].

The suspension polymerisation has also been carried out in $\mathrm{W} / \mathrm{O}$ and $\mathrm{W} / \mathrm{O} / \mathrm{W}$ emulsions, as shown in Table 6. Ma et al. [58] investigated the production of polystyrene-polyacrylamide 
(PSt-PAAm) composite microspheres by combining a SPG emulsification technique for the preparation of $\mathrm{W} / \mathrm{O} / \mathrm{W}$ emulsion and suspension polymerisation. A submicron $\mathrm{W} / \mathrm{O}$ emulsion containing an aqueous solution of AAm dispersed in styrene was first prepared using an ultrasonic homogeniser. This W/O emulsion was then forced through a SPG membrane into the external aqueous phase to prepare a uniform W/O/W emulsion. After polymerisation, the PST-PAAm composite particles containing tiny spherical PAAm-rich microdomains within a PSt matrix were obtained. As amides can be easily hydrolyzed to carboxylic acids or degraded to amines, these PST-PAAm particles are suitable for use as immobilization media of biologically active substances such as proteins and cells. Nagashima et al. [59, 123] attempted production of poly(acrylamide-co-acrylic acid) hydrogel microspheres by polymerisation of aqueous phase droplets in a W/O emulsion. An aqueous mixture of monomers was dispersed into the oil phase using a hydrophobic SPG membranes treated with octadecyltrichlorosilane and trimethylchlorosilane. The W/O emulsion was then subjected to polymerisation at $70^{\circ} \mathrm{C}$ to form hydrogel particles suitable for use in swelling-controlled drug delivery systems. When placed in the body, these particles absorb water or other body fluids and swell. The swelling increases the aqueous solvent content within the formulation as well as the polymer mesh size, enabling the drug to diffuse through the swollen network into the external environment.

Polymer microspheres were also produced using microfabricated channel devices, as can be seen in Table 7. The production of PDVB microspheres using silicon microchannel arrays was investigated by Sugiura et al. [124, 125]. The average diameter of the prepared beads was 3-87 $\mu \mathrm{m}$, depending on the geometry of the MC plate used, and a CV of 4-7 \% was lower than for the beads produced via ME (Tables 5 and 6). The additional advantage 
is that the production of larger beads with the diameter of over $50 \mu \mathrm{m}$ is possible without droplet swelling before polymerisation. Nisisako et al. [32] produced extremely uniform bichromal poly(isobornyl acrylate) beads with a CV of less than $1 \%$ by polymerisation of highly uniform-sized two-colored droplets prepared using a microfluidic system. These bichromal beads comprising a charge adjuvant may find applications in newly developed display media, such as photochromic gyricon display (“electronic paper”) [126].

\subsubsection{Two-stage suspension polymerisation (droplet swelling method)}

The strong hydrophilic nature of SPG favors the formation of uniform microspheres from hydrophobic monomers, such as styrenic monomers. More hydrophilic acrylate monomers tend to yield a wider droplet size distribution due to wetting of the SPG surface. Omi et al. [60] overcame this problem by adopting an Ugelstad and Mørk's swelling technique [127], in which primary hydrophobic droplets, mainly composed of benzene and hexadecane (HD), were swollen in the presence of secondary emulsion droplets consisted of MMA and other more hydrophilic components. Subsequent polymerization yielded PMMA spheres, their $\mathrm{CV}$ being in a comparable range as that of PS spheres. Application of the swelling technique to hydrophobic monomers such as styrene and DVB resulted in larger P(St-coDVB) spheres with the mean size ranging up to $102 \mu \mathrm{m}$ [61]. Here, the seed droplets were composed of DVB, HD, and an initiator, while the secondary emulsion droplets were consisted of more hydrophilic components, a mixture of styrene, middle chain al cohol (C6 to C8), dichlorobenzene, and isoamyl acetate, which promoted a degradative diffusion of the components [61]. 
Table 8 lists investigations on using the swelling technique in combination with SPG emulsification to the preparation of polymer microspheres. The primary (seed) emulsion containing uniform droplets was prepared by SPG emulsification, while the secondary emulsion containing much smaller and more polydisperse droplets was obtained by a conventional rotor-stator homogenisation with a very small amount of emulsifiers (about 0.02 wt. \%). Mixing these two emulsions caused absorption of the hydrophilic monomers from the secondary emulsion in the primary emulsion droplets due to the degradative diffusion mechanism. After all the droplets in the primary emulsion virtually disappeared, the swollen droplets were polymerised in the same way as in a single-stage polymerisation process. Despite the polydispersity of the secondary emulsion, the swollen droplets retain the uniformity of the primary emulsion, even when their volume has been increased up to several thousands times due to swelling [61]. Figure 10 illustrates a schematic flowsheet for the manufacture of both hydrophilic and hydrophobic spheres.

\subsubsection{Solvent evaporation method}

ME techniques have been applied to the preparation of microspheres using an organic solution of a preformed polymer as a disperse oil phase. The process is not dissimilar from that used in XMC (above). After the uniform droplets were prepared, the volatile solvent such as methylene chloride, chloroform, toluene, etc was evaporated. This technique has been applied to manufacture polylactide (PLA) and poly(lactide-co-glycolide) (PLGA) biodegradable microspheres [65, 128], polystyrene-poly(methyl methacrylate) (PStPMMA) composite microspheres [63, 64], and polymer microcapsules containing magnetite $\left(\mathrm{Fe}_{3} \mathrm{O}_{4}\right)$ [68] or $\mathrm{TiO}_{2}$ [66] (Table 9). Also, uniform PUU particles were prepared by solvent evaporation from PUU-xylene droplets after the PU pre-polymer underwent a 
chain-extending reaction at room temperature with a diamine reagent $(\mathrm{Pz})$ [62]. One of the disadvantages of solvent evaporation is that no crosslinked polymers can be incorporated into microspheres [122].

In the production of PLA and PSt-PMMA microspheres, the preformed polymer (PLA or a mixture of PSt and PMMA) was dissolved in solvent (dichloromethane) containing LOH or HD as a cosurfactant. The role of cosurfactant was 1) to increase the hydrophobicity of the oil phase, thereby preventing the membrane wall from being wetted with the disperse phase; and 2) to prevent the oil phase from diffusing into the aqueous phase so that the stability of the droplets could be maintained. $\mathrm{LOH}$ was found to be more efficient than HD in providing uniform-sized microspheres [65].

Conventionally, droplets of preformed polymer solution are prepared by agitation, rotorstator homogenisation, sonication, microfluidisation, etc [130, 131]. Compared with the traditional methods, the membrane technique can provide more uniform droplets with the CV of $10 \%$. Due to narrow size distribution, the droplets do not tend to coalesce or redisperse during solvent evaporation. In addition, the mean droplet size can be controlled easily and exactly by using SPG membranes with different mean pore sizes.

3.9 Production of hollow polymer particles and core-shell microcapsules

Microencapsulation is defined as the embedding of at least one ingredient (active agent or core) into at least one other (shell material). Two of the main capsule structures are 1) embedded particles (or core) in the shell of the capsule (matrix microcapsules), 2) a 
continuous shell surrounding the core (core-shell microcapsules). Core-shell microcapsules are preferred if the active agent should be released slowly over a very long time. Microcapsules are used in many different applications in chemical, cosmetic and food industries. Ma et al. [69] prepared uniform core-shell microcapsules with HD as a core and polystyrene or poly(St-co-DMAEMA) as a shell using SPG emulsification technique and a subsequent suspension polymerisation. The reason for the complete encapsulation of HD was a much smaller interfacial tension at the polymer/aqueous phase interface than at the HD/aqueous phase interface. As a result, the polymer phase tends to accumulate near the aqueous phase forming a shell, which completely surrounds HD. When the monomer conversion was lower, the monomer was partitioned between HD and the PSt phase. Consequently, the interfacial tension at the HD/aqueous phase interface was reduced, resulting in the leakage of HD from the capsule and a hole was observed on the surface. Incorporation of DMAEMA decreased the interfacial tension between the polymer and aqueous phase and HD could be encapsulated completely even when monomer conversion was lower [69]. The core size was controlled by the HD content. By adding crosslinking agent (DVB), solid microspheres instead of core-shell microcapsules were formed.

Hollow particles are used as opacifying plastic pigments for various coatings and glossenhancing plastic pigments, as a light-weight reinforcement material, a light scattering material, etc [72]. Omi et al. [75] produced poly(MMA-co-EGDMA-co-2-EHA) hollow particles by two-stage suspension polymerisation. Uniform seed droplets composed of a heptane/benzene (4:1) mixture, initiator and 2-EHA were first prepared using a SPG membrane. This emulsion was then mixed with a fine secondary emulsion composed of hydrophilic monomers (MMA and EGDMA), prepared using a homogenizer. The oil phase 
of the secondary emulsion was absorbed by the seed droplets and the swollen droplets were then subjected to polymerisation. Because the polymer was more hydrophilic than the solvents, the phase separation occurred, with the solvents localized in the center and with a polymer network as a shell. After the solvents were extracted, hollow particles were obtained. A crosslinking agent (EGDMA) and a low Tg monomer (2-EHA) were added to reinforce the polymer wall and to provide elasticity [75]. If a good solvent (benzene) was added in excess, a porous structure prevailed. Ma et al. [74] prepared poly(St-coDMAEMA) hollow particles by one-stage suspension polymerisation using a mixture of St, DMAEMA, HD and ADVN as a disperse phase and an aqueous phase containing SLS, PVP, and $\mathrm{NaNO}_{2}$ as a continuous phase. The preparation procedure was similar to the preparation of core-shell microcapsules described above.

Chu et al. $[70,71]$ produced monodisperse termosensitive core-shell microcapsules with a porous PA membrane as a shell and linear-grafted PNIPAAm chains in the membrane pores acting as thermoresponsive gates (Figure 11). An O/W emulsion containing TDS monomer dissolved in a mixture of organic solvents as a disperse phase and the aqueous solution of emulsifier (SDS or Tween 80) and stabiliser (PVA) as a continuous phase was prepared by SPG emulsification. A buffer solution containing EMA monomer was then added to the emulsion and core-shell microcapsules with a mean pore size of $4 \mu \mathrm{m}$ were formed by interfacial polymerisation [132]. Plasma-graft pore-filling polymerization was used to graft linear PNIPAAm chains into the pores of the microcapsule membranes. The prepared PNIPAAm-grafted monodisperse microcapsules with an average diameter of about $4 \mu \mathrm{m}$ showed satisfactory reversible and reproducible thermoresponsive release characteristics. The release of both $\mathrm{NaCl}$ and vitamin B12 from the microcapsules was 
slow at $25{ }^{\circ} \mathrm{C}$ and fast at $40{ }^{\circ} \mathrm{C}$, which was due to the closed/open state of the grafted “gates”.

When emulsification was carried out using a traditional mechanical stirring method, polydisperse core-shell microcapsules with an average size of about $40 \mu \mathrm{m}$ were prepared [132]. For drug delivery systems, monodisperse small-sized microcapsules are more favorable than polydisperse large-sized microcapsules, because there is a size limit for particles to traverse certain organs and a small particle size minimizes any potential irritant reaction at the injection site. A uniform microcapsule size is important to create more sophisticated systems in which the drug release kinetics can be more accurately controlled.

\subsection{Production of colloidal assemblies}

The uniform-sized colloidal assemblies have a number of potential applications such as particles for "electronic paper” and size-exclusion chromatography, photocatalyst supports, model colloids for complex colloidal particles, nano-bar codes for the recognition of biological molecules [33]. Yi et al. [33] reported the fabrication of 3D colloidal assemblies with narrow size distribution, in which monodisperse PS beads with a diameter of 1 or 2 $\mu \mathrm{m}$ were assembled into a regular arrangement. Mono-sized aqueous droplets containing the latex beads were first dispersed into silicon oil using a microfluidic device. Then, the S/W/O dispersions were converted to uniform colloidal assemblies of latex spheres by slowly removing water from the aqueous droplets. Similarly, Yi et al. [133] produced uniform 3D assemblies of sub-micrometer monodisperse colloidal particles, so-called 
photonic balls that may be used as photonic crystals and light diffusers in a wide variety of applications.

\section{Conclusions}

All the investigations carried out so far show that membrane emulsification offers great potential in manufacturing 'made-to-measure' emulsions and other solid particulates. The process is reliable, and suitable to large scale productions, as scale-up is mainly based on multiplication of small scale processing units (e.g., membrane modules) rather than the simple enlargement of processing vessel sizes. Both single (W/O or $\mathrm{O} / \mathrm{W})$ and multiple (W/O/W, E/O/W or $\mathrm{O} / \mathrm{W} / \mathrm{O}$ ) emulsions, with various droplets sizes ranging from 0.8 to over $100 \mu \mathrm{m}$, and a typical coefficient of variation of $10-15 \%$, have been successfully prepared by employing different pore sizes and types of membranes. It is envisaged that direct membrane emulsification can be a specially attractive technique for small scale manufacture of low viscosity, low concentration emulsion products, due to its high capability of droplet size and distribution controls but limited emulsifying rate. Premix membrane emulsification is a technique potentially suitable for large scale manufacture of high concentration emulsion products, due to high emulsifying rate and simple operation.

Membrane emulsification has also been adopted for the precision manufacture of solids. To date, several different types of particles have been successfully produced by incorporating use of membranes in processes of polymerisation, gelation, crystallization, and encapsulation. The approach has a future potential of enabling formations of a variety of high specification particulates, such as ones not only with monodispersed size and 
distributions, but also having a demanding tolerance on the particle shape, surface functional group and crystal orientations. The end product would be a particle suspension, with tailor-made chemical activities and macroscopic rheological behaviours to meet modern demand for 'smart' particles in a wide range of manufacture industries.

\section{Abbreviations of Chemicals}

AA: acrilic acid

AAm: acrylamide

ADVN: N,N'-azobis(2,4

dimethylvaleronitrile)

AIBN: 2,2'-azobis(isobutyronitrile)

ASt: acetoxystyrene

BA: butyl acrylate

BAc: butyl acetate

BANI-M: diphenylmethane-4,49-bis-

allylnagiimide

BLG: $\beta$-lactoglobulin

BMA: butyl methacrylate

BPO: benzoyl peroxide

BuOH: butanol

Bz: benzene

CA: cetyl alcohol

CAS: caseinate
CHA: cyclohexyl acrylate

CHx: cyclohexane

CTMABr: cetyltrimethyl ammonium

bromide

DAP: diaminophenylene

DAROCUR $^{\circledR} 1173$ : initiator of photo-

induced polymerisation

DCB: o-dichlorobenzene

DCM: dichloromethane

DD: dodecane

DHBSP: 2.5-dihydrozybenzenedisulfonic acid, dipotassium salt

Disperbyk-111 or 180: dispersing additives of BYK-Chemie

DMAEMA: dimethylaminoethyl

methacrylate

DOP: dioctyl phthalate 
DVB: divinylbenzene

EA: ethyl acetate

EDA: ethylene diamine

EGDMA: ethylene glycol dimethacrylate

2-EHA: 2-ethylhexyl acrylate

2-EHMA: 2-ethylhexyl methacrylate

E-81: a charge control agent

GMA: glycidyl methacrylate

HA: hexanol

HD: hexadecane

HDOH: hexadecanol

HDDA: 1,6-hexanediol diacrylate

HEMA: 2-hydroxyethyl methacrylate

Hp: heptane

HQ: hydroquinone

Hx: hexane

IA: isoamyl acetate

IBOA: isobornyl acrylate

IO: Isooctane

KPS: potassium persulfate

LA: lauryl acrylate

LMA: lauryl methacrylate

LOH: lauryl alcohol

MA: methyl acrylate
MBAAm: $N, N$ '-methylene-bis-

acrylamide

MCT: medium chain triglycerides

ML: methyl laurate

MMA: methyl methacrylate

4-MP: 4-methyl-2-pentanol

MP: methyl palmitate

MST-1: stabiliser of Nippon NSC Ltd.

OA: octanol

PA: polyamide

PASt: polyacetostyrene

PDA: p-phenylenediamine

PDMS: polydimethylsiloxane

PEGMMA: polyethylene glycol

monomethacrylate

PEGPMMA: polyethylene glycol

polymethacrylate

PGPG 90: polyglycerol polyricinoleate

PIP: polyimide prepolymer

PLA: Polylactide acid

PMMA: polymethyl methacrylate

PNIPAAm: poly( $N$-isopropylacrylamide)

PSt: polystyrene

PUU: polyurethaneurea 
PVA: polyvinyl alcohol

PVP: polyvinyl pyrrolidone

Pz: piperazine

SBR: styrene-butadiene rubber

SDS: sodium dodecyl sulfate

SLS: sodium lauryl sulfate

Span 20: sorbitan monolaurate

Span 60: sorbitan monostearate

Span 80: sorbitan monooleate

Span 85: sorbitan trioleate

SPBS: Sumiplast Blue S (colorant)

St: styrene

SUNSOFT818H: oil-soluble surfactant

t-BPP: tert-butyl peroxypivalate

TCB: trichlorobenzene

TDS: terephthaloyl dichloride

TGCR: tetraglycerin condensed

ricinoleate

Tl: toluene

TMEDA: N,N,N',N'-

tetramethylethylenediamine

TMPTMA: trimethyolpropane

trimethacrylate
TOMAC: tri-n-octylmethyl ammonium

chloride

Tween 20: polyoxyethylene (20) sorbitan

monolaurate

Tween 85: polyoxyethylene (20) sorbitan

trioleate

VP: vinyl polymer

Xl: Xylen 


\section{Acknowledgement}

This work is partially supported by a Royal Society (UK, London) grant.

\section{References:}

[1] T. Nakashima, M.Shimizu, Ceramics Japan 21 (1986) 408 (in Japanese).

[2] T. Nakashima, M. Shimizu, M. Kukizaki, Membrane emulsification operation manual, Department of Chemistry, Industrial Research Institute of Miyazaki Prefecture, Miyazaki, 1991.

[3] T. Nakashima, M. Shimizu, M. Kukizaki, Membrane emulsification by microporous glass, Proc. $2^{\text {nd }}$ International Conference on Inorganic Membranes, Montpellier, 1-4 July 1991, p. 513.

[4] T. Nakashima, M. Shimizu, M. Kukizaki, Key Eng. Mater. 61-62 (1991) 513.

[5] S. M. Joscelyne, G. Trägårdh, J. Food Eng. 39 (1999) 59.

[6] V. Schröder, O. Behrend, H. Schubert, J. Colloid Interface Sci. 202 (1998) 334.

[7] A. J. Abrahamse, R. Van Lierop, R. G. M. Van der Sman, A. Van der Padt, R. M. Boom, J. Membr. Sci. 204 (2002) 125.

[8] L. Giorno, N. Li, E. Drioli, J. Membr. Sci. 217 (2003) 173.

[9] R. A. Williams, S. J. Peng, D. A. Wheeler, N. C. Morley, D. Taylor, M. Whalley, D. W. Houldsworth, Chem. Eng. Res. Des. 76 A (1998) 902.

[10] V. Schröder, Herstellen von Öl-in-Wasser-Emulsionen mit mikroporösen Membranen, Ph. D. thesis, University of Karlsruhe (T.H.), Karlsruhe, 1999.

[11] G. T. Vladisavljević, H. Schubert, J. Dispersion Sci. Technol. 24 (2003) 811. 
[12] S. Berot, S. Giraudet, A. Riaublanc, M. Anton, Y. Popineau, Chem. Eng. Res. Des. 81 A (2003) 1077.

[13] T. Yanagishita, Y. Tomabechi, K. Nishio, H. Masuda, Langmuir 20 (2004) 554.

[14] T. Fuchigami, M. Toki, K. Nakanishi, J. Sol-Gel Sci. Techn. 19 (2000) 337.

[15] P. J. Dowding, J. W. Goodwin, B. Vincent, Colloid. Surf. A 180 (2001) 301.

[16] R. A. Williams, Controlled dispersion using a spinning membrane reactor, UK Patent Application No. PCT/GB00/04917 (2001).

[17] X. D. Liu, D. C. Bao, W. M. Xue, Y. Xiong, W. T. Yu, X. J. Yu, X. J. Ma, Q. Yuan, J. Appl. Polym. Sci. 87 (2003) 848.

[18] G. T. Vladisavljević, S. Brösel, H. Schubert, Chem. Eng. Process. 41 (2002) 231.

[19] K. Suzuki, I. Fujiki, Y. Hagura, Food Sci. Technol. Int. Tokyo 4 (1998) 164.

[20] K. Suzuki, I. Fujiki, Y. Hagura, Food Sci. Technol. Int. Tokyo 5 (1999) 234.

[21] J. Altenbach-Rehm, H. Schubert, K. Suzuki, Chem. Ing. Tech. 74 (2002) 587.

[22] J. Altenbach-Rehm, K. Suzuki, H. Schubert, Production of O/W-emulsions with narrow droplet size distribution by repeated premix membrane emulsification, Proc. $3^{\text {rd }}$ World Congress on Emulsions, Lyon, 24-27. September 2002.

[23] N. Yamazaki, H. Yuyama, M. Nagai, G. H. Ma, S. Omi, J. Dispersion Sci. Technol. 23 (2002) 279.

[24] K. Naganuma, M. Nagai, G. H. Ma, S. Omi, J. Dispersion Sci. Technol. 24 (2003) 249.

[25] I. Kobayashi, M. Yasuno, S. Iwamoto, A. Shono, K. Satoh, M. Nakajima, Colloid. Surf. A 207 (2002) 185.

[26] S. H. Park, T. Yamaguchi, S. Nakao, Chem. Eng. Sci. 56 (2001) 3539. 
[27] M. Shima, Y. Kobayashi, T. Fujii, M. Tanaka, Y. Kimura, S. Adachi, R. Matsuno, Food Hydrocolloids 18 (2004) 61.

[28] A. J. Gijsbertsen-Abrahamse, A. Van der Padt, R. M. Boom, J. Membr. Sci. 217 (2003) 141.

[29] I. Kobayashi, M. Nakajima, K. Chun, Y. Kikuchi, H. Fujita, AIChE J. 48 (2002) 1639.

[30] I. Kobayashi, M. Nakajima, S. Mukataka, Colloid. Surf. A 229 (2003) 33.

[31] T. Kawakatsu, G. Trägårdh, Y. Kikuchi, M. Nakajima, H. Komori, T. Yonemoto, J. Surfactants Deterg. 3 (2000) 295.

[32] T. Nisisako, T. Torii, T. Higuchi, Chem. Eng. J. 101 (2004) 23.

[33] G. R. Yi, T. Thorsen, V. N. Manoharan, M. J. Hwang, S. J. Jeon, D. J. Pine, S. R. Quake, S. M. Yang, Adv. Mater. 15 (2003) 1300.

[34] T. Nakashima, M. Shimizu, M. Kukizaki, Adv. Drug Deliv. Rev. 45 (2000) 47.

[35] S. Higashi, T. Setoguchi, Adv. Drug Deliv. Rev. 45 (2000) 57.

[36] S. Higashi, M. Shimizu, T. Nakashima, K. Iwata, F. Uchiyama, S. Tateno, T. Setoguchi, Cancer 75 (1995) 1245.

[37] T. Nakashima, History of SPG technology and its recent advances, Proc. $38^{\text {th }}$ Int. SPG Forum "Membrane and Particle Science and Technology in Food and Medical Care, Miyazaki, 21-22. November 2002, p. 63.

[38] S. Okonogi, R. Katoh, Y. Asano, H. Yuguchi, R. Kumazawa, K. Sotoyama, K. Takahashi, M. Fujimoto, US Patent 5,279,847 (1994).

[39] M. Nakajima, H. Nabetani, S. Ichikawa, Q. Y. Xu, Functional emulsions, US Patent 6,538,019 (2003).

[40] T. Kawakatsu, G. Trägårdh, C. Trägårdh, Colloid. Surf. A 189 (2001) 257. 
[41] E. Toorisaka, H. Ono, K. Arimori, N. Kamiya, M. Goto, Int. J. Pharm. 252 (2003) 271.

[42] M. Shimizu, K. Torigoe, I. Akazaki, T. Nakashima, Preparation of monodispersed solder microspheres by membrane emulsification, Proc. $36^{\text {th }}$ SPG Forum "Various Applications of Membrane and Particles in Healthcare Fields”, Miyazaki, 6-7. December 2001, p. 78.

[43] K. Kandori, K. Kishi, T. Ishikawa, Colloid. Surf. 62 (1992) 259.

[44] S. Sugiura, M. Nakajima, J. Tong, H. Nabetani, M. Seki, J. Colloid Interface Sci., 227 (2000) 95.

[45] I. Kobayashi, Y. Iitaka, S. Iwamoto, S. Kimura and M. Nakajima, J. Chem. Eng. Jpn. 36 (2003) 996.

[46] S. Iwamoto, K. Nakagawa, S. Sugiura, M. Nakajima, AAPS Pharmsci 3, article 25 (2002) 1.

[47] J. O. You, S. B. Park, H. Y. Park, S. Haam, C. H. Chung, W. S. Kim, J. Microencapsul. 18 (2001) 521.

[48] J. Weiss, K. Kobow, G. Muschiolik, Preparation of microgels by membrane emulsification, Proc. Food Colloids 2004, Harogate, 18-21 April 2004.

[49] D. Gladman, R. Williams, Chemical Engineer (London) n. 748, October (2003) 32.

[50] C. S. Senathirajah, Precision manufacture of solid particulates using cross membrane crystallization (XMC), Ph. D. thesis, University of Leeds, 2004.

[51] M. el-Mahdy, E. S. Ibrahim, S. Safwat, A. el-Sayed, H. Ohshima, K. Makino, N. Muramatsu, T. Kondo, J. Microencapsul. 15 (1998) 661.

[52] N. Muramatsu, T. Kondo, J. Microencapsul. 2 (1995) 129.

[53] N. Muramatsu, K. Nakauchi, J. Microencapsul. 15 (1998) 715. 
[54] H. Yuyama, T. Hashimoto, G. H. Ma, M. Nagai, S. Omi, J. Appl. Polym. Sci. 78 (2000) 1025.

[55] S. Omi, K. Katami, A. Yamanoto, M. Iso, J. Appl. Polym. Sci. 51 (1994) 1.

[56] R. Nuisin, G. H. Ma, S. Omi, S. Kiatkamjornwong, J. Appl. Polym. Sci. 77 (2000) 1013.

[57] G. H. Ma, C. J. An, H. Yuyama, Z. G. Su, S. Omi, J. Appl. Polym. Sci. 89 (2003) 163.

[58] G. H. Ma, H. Sone, S. Omi, Macromolecules 37 (2004) 2954.

[59] S. Nagashima, S. Ando, T. Tsukamoto, H. Ohshima, K. Makino, Colloid. Surf. B 11 (1998) 47.

[60] S. Omi, K. Katami, T. Taguchi, K. Kaneko, M. Iso, J. Appl. Polym. Sci. 57 (1995) 1013.

[61] S. Omi, T. Taguchi, M. Nagai, G. H. Ma, J. Appl. Polym. Sci. 63 (1997) 931.

[62] H. Yuyama, K. Yamamoto, K. Shirafuji, M. Nagai, G. H. Ma, J. Appl. Polym. Sci. 77 (2000) 2237.

[63] G. H. Ma, M. Nagai, S. Omi, J. Colloid Interface Sci. 214 (1999) 264.

[64] G. H. Ma, M. Nagai, S. Omi, J. Colloid Interface Sci. 219 (1999) 110.

[65] G. H. Ma, M. Nagai, S. Omi, Colloid. Surf. A 153 (1999) 383.

[66] A. Supsakulchai, G. H. Ma, M. Nagai, S. Omi, J. Microencapsul. 19 (2002) 425.

[67] A. Supsakulchai, G. H. Ma, M. Nagai, S. Omi, ACS Symposium Series 801 (2002) 260.

[68] S. Omi, A. Kanetaka, Y. Shimamori, A. Supsakulchai, M. Nagai, G. H. Ma, J. Microencapsul. 19 (2001) 749.

[69] G. H. Ma, Z. G. Su, S. Omi, D. Sundberg, J. Stubbs, J. Colloid Interface Sci. 266 (2003) 282. 
[70] L. Y. Chu, R. Xie, J. H. Zhu, W. M. Chen, T. Yamaguchi, S. Nakao, J. Colloid Interface Sci. 265 (2003) 187.

[71] L. Y. Chu, S. H. Park, T. Yamaguchi, S. Nakao, Langmuir 18 (2002) 1856.

[72] G. H. Ma, A. Y. Chen, Z. G. Su, S. Omi, J. Appl. Polym. Sci. 87 (2003) 244.

[73] G. H. Ma, S. Omi, V. L. Dimonie, E. D. Sudol, M. S. El-Aasser, J. Appl. Polym. Sci. 85 (2002) 1530.

[74] G. H. Ma, M. Nagai, S. Omi, J. Appl. Polym. Sci. 79 (2001) 2408.

[75] S. Omi, G. H. Ma, M. Nagai, Macromol. Symp. 151 (2000) 319.

[76] R. A. Williams, Ingenia n. 7, February (2001) 1.

[77] SPG Tecnology Co., Internal pressure type micro kit, typ MN-20, Data Sheet, 2003.

[78] Y. Hatate, H. Ohta, Y. Uemura, K. Ijichi, H. Yoshizawa, J. Appl. Polym. Sci. 64 (1997) 1107.

[79] S. Sugiura, M. Nakajima, N. Kumazawa, S. Iwamoto, M. Seki, J. Phys. Chem. B 106 (2002) 9405.

[80] G. T. Vladisavljević, U. Lambrich, M. Nakajima, H. Schubert, Colloid. Surf. A 232 (2004) 199.

[81] R. Katoh, Y. Asano, A. Furuya, K. Sotoyama, M. Tomita, J. Membr. Sci. 113 (1996) 131.

[82] T. Nakashima, M. Shimizu, M. Kukizaki, Kag. Kog. Ronbunshu 19 (1993) 991 (in Japanese).

[83] M. Shimizu, T. Nakashima, M. Kukizaki, Kag. Kog. Ronbunshu 28 (2002) 304 (in Japanese).

[84] M. Shimizu, T. Nakashima, M. Kukizaki, Kag. Kog. Ronbunshu 28 (2002) 310 (in Japanese). 
[85] G. T. Vladisavljević, H. Schubert, Desalination 144 (2002) 167.

[86] G. T. Vladisavljević, H. Schubert, J. Membr. Sci. 225 (2003) 15.

[87] R. A. Williams, Emulsifying with membranes, Proc. $3^{\text {rd }}$ World Congress on Emulsions, Lyon, 24-27. September 2002.

[88] K. Suzuki, I. Shuto, Y. Hagura, Food Sci. Technol. Int. Tokyo 2 (1996) 43.

[89] G. Akay, Chem. Eng. Sci. 53 (1998) 203.

[90] Y. Kawashima, T. Hino, H. Takeuchi, T. Niwa, K. Horibe, J. Colloid Interface Sci. 145 (1991) 512.

[91] T. Hino, Y. Kawashima, S. Shimabayashi, Adv. Drug Deliv. Rev. 45 (2000) 27.

[92] G. T. Vladisavljević, M. Shimizu, T. Nakashima, Preparation of monodisperse multiple emulsions at high production rates by multi-stage premix membrane emulsification, J. Membr. Sci., in press.

[93] S. M. Joscelyne, G. Trägårdh, J. Membr. Sci. 169 (2000) 107.

[94] C. Charcosset, I. Limayem, H. Fessi, J. Chem. Technol. Biotechnol. 79 (2004) 209.

[95] U. Lambrich, G. T. Vladisavljević, Chem. Ing. Tech. 76 (2004) 376.

[96] A. J. Gijsbertsen-Abrahamse, A. Van der Padt, R. M. Boom, J. Membr. Sci. 230 (2004) 149.

[97] A. J. Abrahamse, A. Van der Padt, R. M. Boom, W. B. C. De Heij, AIChE J. 47 (2001) 1285.

[98] S. van der Graaf, C. G. P. H. Schroën, R. G. M. van der Sman, R. M. Boom, J. Colloid Interface Sci. 277 (2004) 456.

[99] H. Yuyama, T. Watanabe, G. H. Ma, M. Nagai, S. Omi, Colloid. Surf. A 168 (2000) 159. 
[100] N. C. Christov, D. N. Ganchev, N. D. Vassileva, N. D. Denkov, K. D. Danov, P. A. Kralchevsky, Colloid. Surf. A 209 (2002) 83.

[101] T. Nakashima, M. Shimizu, M. Kukizaki, US Patent 5,326,484 (1994).

[102] G. T. Vladisavljević, M. Shimizu, T. Nakashima, Permeability of hydrohilic and hydrophobic Shirasu-porous-glass (SPG) membranes to pure liquids and its microstructure, J. Membr. Sci., in press.

[103] Y. Mine, M. Shimizu, T. Nakashima, Colloid. Surf. B 6 (1996) 261.

[104] S. Sugiura, M. Nakajima, K. Yamamoto, S. Iwamoto, T. Oda, M. Satake, M. Seki, J. Colloid Interface Sci. 270 (2004) 221.

[105] M. Shimizu, M. Kukizaki, T. Nakashima, A. M. Alvarez-Nakase, Leakage of inclosed irinotecan hydrochloride and remedial measures taken during production of the W/O type oral medicine, Proc. $38^{\text {th }}$ Int. SPG Forum "Membrane and Particle Science and Technology in Food and Medical Care, Miyazaki, 21-22. November 2002.

[106] S. Gouin, Trends Food Sci. Technol. 15 (2004) 330.

[107] S. Omi, Colloid. Surf. A 109 (1996) 97.

[108] G. Ma, China Particuology 1 (2003) 105.

[109] Y. Hatate, Y. Uemura, K. Ijichi, Y. Kato, T. Hano, J. Chem. Eng. Jpn. 28 (1995) 656.

[110] K. Hosoya, K. Yoshizako, K. Kimata, N. Tanaka, Chromatography 18 (1997) 226.

[111] K. Hosoya, H. Ohta, K. Yoshizako, K. Kimata, T. Ikegami, N. Tanaka, J. Chromatogr. A 853 (1999) 11.

[112] H. Yoshizawa, M. Maruta, S. Ikeda, Y. Hatate, Y. Kitamura, Colloid. Polym. Sci. 282 (2004) 965.

[113] D. Westover, W. R. Seitz, B. K. Lavine, Microchem. J. 74 (2003) 121. 
[114] S. Omi, K. Kaneko, A. Nakayama, K. Katami, T. Taguchi, M. Iso, M. Nagai, G. H. Ma, J. Appl. Polym. Sci. 65 (1997) 2655.

[115] Y. K. Ha, H. S. Song, H. J. Lee, J. H. Kim, Colloid. Surf. A 162 (2000) 289.

[116] S. Kiatkamjornwong, N. Roongkan, G. H. Ma, S. Omi, Chin. J. Polym. Sci. 18 (2000) 308.

[117] G. H. Ma, J. Fujiwara, Z. G. Su, S. Omi, J. Appl. Polym. Sci. 41 (2003) 2588.

[118] S. Omi, A. Matsuda, K. Imamura, M. Nagai, G. H. Ma, Colloid. Surf. A 153 (1999) 373.

[119] R. Nuisin, S. Omi, S. Kiatkamjornwong, J. Appl. Polym. Sci. 90 (2003) 3037.

[120] Y. K. Ha, H. J. Lee, J. H. Kim, Colloid. Surf. A 145 (1998) 281.

[121] S. Tawonsree, S. Omi, S. Kiatkamjornwong, J. Appl. Polym. Sci. 38 (2000) 4038.

[122] A. Supsakulchai, G. H. Ma, M. Nagai, S. Omi, J. Microencapsul. 20 (2003) 1.

[123] S. Nagashima, M. Koide, S. Ando, K. Makino, T. Tsukamoto, H. Ohshima, Colloid. Surf. A 153 (1999) 221.

[124] S. Sugiura, M. Nakajima, M. Seki, Ind. Eng. Chem. Res. 41 (2002) 4043.

[125] S. Sugiura, M. Nakajima, H. Itou, M. Seki, Macromol. Rapid Commun. 22 (2001) 773.

[126] D. A. Foucher, R. D. Patel, N. Chopra, P. M. Kazmaier, E. Buncel, J. Wojtyk, US Patent 6,549,327 (2003).

[127] J. Ugelstad, P. C. Mørk, Adv. Colloid Interface Sci. 13 (1980) 101.

[128] K. Shiga, N. Muramatsu, T. Kondo, J. Pharm. Pharmacol. 48 (1996) 891.

[129] G. H. Ma, M. Nagai, S. Omi, J. Appl. Polym. Sci. 66 (1997) 1325.

[130] P. B. O’Donnell, J. W. James, Adv. Drug Deliv. Rev. 28 (1997) 25.

[131] R. A. Jain, Biomaterials 21 (2000) 2475. 
[132] L. Y. Chu, S. H. Park, T. Yamaguchi, S. Nakao, J. Membr. Sci. 192 (2001) 27.

[133] G. R. Yi, S. J. Jeon, T. Thorsen , V. N. Manoharan, S. R. Quake, D. J. Pine, S. M. Yang, Synthetic Metals 139 (2003) 803. 


\section{Tables}

Table 1: Microporous membranes other than Shirasu Porous Glass (SPG) used by different investigators for membrane emulsification.

\begin{tabular}{|c|c|c|c|c|c|}
\hline Membrane material & $\begin{array}{l}\text { Membrane } \\
\text { form }\end{array}$ & $\begin{array}{l}\text { Inherent } \\
\text { surface } \\
\text { affinity } \\
\end{array}$ & $\begin{array}{l}\text { Mean } \\
\text { pore } \\
\text { size } \\
\end{array}$ & $\begin{array}{c}\text { Effective } \\
\text { membrane } \\
\text { area } \\
\end{array}$ & Ref. \\
\hline $\begin{array}{c}\text { Coated } \alpha \text {-alumina or } \\
\text { zirconia }\end{array}$ & Tubular & Hydrophilic & $\begin{array}{c}0.02-3 \\
\mu \mathrm{m}\end{array}$ & $\begin{array}{c}50-460 \\
\mathrm{~cm}^{2}\end{array}$ & {$[9-12,5]$} \\
\hline Anodic porous alumina & Flat & Hydrophilic & $\begin{array}{c}0.125 \\
\mu \mathrm{m}\end{array}$ & - & [13] \\
\hline $\begin{array}{l}\text { Sol-gel porous glass } \\
\text { (sol-gel PG) }\end{array}$ & Tubular & Hydrophilic & $0.6 \mu \mathrm{m}$ & - & {$[14]$} \\
\hline $\begin{array}{l}\text { Stainless steel with } \\
\text { laser drilled pores }\end{array}$ & Tubular & Hydrophilic & $\begin{array}{c}100-150 \\
\mu \mathrm{m}\end{array}$ & $4 \mathrm{~cm}^{2}$ & {$[15,16]$} \\
\hline Microporous nickel & Tubular & Hydrophilic & $\begin{array}{c}2.9-5.2 \\
\mu \mathrm{m}\end{array}$ & - & [17] \\
\hline Polypropylene & $\begin{array}{l}\text { Hollow } \\
\text { fiber }\end{array}$ & Hydrophobic & $0.4 \mu \mathrm{m}$ & $10^{3} \mathrm{~cm}^{2}$ & [18] \\
\hline Polyamide & $\begin{array}{l}\text { Hollow } \\
\text { fiber }\end{array}$ & Hydrophilic & $10 \mathrm{~nm}$ & $36 \mathrm{~cm}^{2}$ & {$[8]$} \\
\hline $\begin{array}{l}\text { Polytetrafluoroethylene } \\
\text { (PTFE) }\end{array}$ & Flat & $\begin{array}{l}\text { Hydrophilic } \\
\text { or } \\
\text { hydrophobic }\end{array}$ & $\begin{array}{c}0.5-5 \\
\mu \mathrm{m}\end{array}$ & $3-17 \mathrm{~cm}^{2}$ & [19-24] \\
\hline $\begin{array}{l}\text { Polycarbonate, } \\
\text { track-etched }\end{array}$ & Flat & Hydrophilic & $\begin{array}{c}0.6-10 \\
\mu \mathrm{m}\end{array}$ & $1.5-14 \mathrm{~cm}^{2}$ & {$[25,26]$} \\
\hline Cellulose acetate & Flat & Hydrophilic & $\begin{array}{c}0.2-3 \\
\mu \mathrm{m}\end{array}$ & $4 \mathrm{~cm}^{2}$ & [27] \\
\hline $\begin{array}{l}\text { Microengineered } \\
\text { silicone nitride } \\
\text { microsieve }\end{array}$ & Flat & Hydrophilic & $7 \mu \mathrm{m}$ & $3 \cdot 10^{-4} \mathrm{~cm}^{2}$ & {$[7,28]$} \\
\hline $\begin{array}{c}\text { Straight-through } \\
\text { silicon microchannels }\end{array}$ & Flat & Hydrophilic & $\begin{array}{c}10-17 \\
\mu \mathrm{m}\end{array}$ & $1 \mathrm{~cm}^{2}$ & {$[29,30]$} \\
\hline
\end{tabular}


Table 2: Secondary products of membrane and microchannel emulsification.

\begin{tabular}{|c|c|c|c|}
\hline Product type & Example & $\begin{array}{l}\text { Secondary reaction/process after } \\
\text { primary emulsification }\end{array}$ & Ref. \\
\hline W/O spreads & Stable low-fat food spreads & Chilling/kneading & [34] \\
\hline $\begin{array}{l}\mathrm{W}_{1} / \mathrm{O} / \mathrm{W}_{2} \\
\text { emulsions }\end{array}$ & $\begin{array}{l}\text { Drug and nutrient delivery } \\
\text { systems }\end{array}$ & $\begin{array}{l}\text { Emulsification of } \mathrm{W}_{1} / \mathrm{O} \text { emulsion in } \\
\text { external water phase } \mathrm{W}_{2}\end{array}$ & {$[34-37]$} \\
\hline $\begin{array}{l}\mathrm{O}_{1} / \mathrm{W} / \mathrm{O}_{2} \\
\text { emulsions }\end{array}$ & Food emulsions & $\begin{array}{l}\text { Emulsification of } \mathrm{O}_{1} / \mathrm{W} \text { emulsion in } \\
\text { external oil phase } \mathrm{O}_{2}\end{array}$ & [38] \\
\hline $\begin{array}{l}\mathrm{E} / \mathrm{O} / \mathrm{W} \\
\text { emulsions }\end{array}$ & $\begin{array}{l}\text { Polyphenol-enriched } \\
\text { emulsions }\end{array}$ & $\begin{array}{l}\text { Emulsification of E/O emulsion in } \\
\text { water phase }\end{array}$ & [39] \\
\hline \multirow{2}{*}{$\begin{array}{l}\text { S/O/W } \\
\text { dispersions }\end{array}$} & $\mathrm{S} / \mathrm{O} / \mathrm{W}$ pectin microcapsules & $\begin{array}{l}\text { Gelation of internal water phase } \mathrm{W}_{1} \\
\text { in } \mathrm{W}_{1} / \mathrm{O} / \mathrm{W}_{2} \text { emulsion }\end{array}$ & {$[40]$} \\
\hline & $\begin{array}{l}\text { Medicine for oral } \\
\text { administration of insulin }\end{array}$ & $\begin{array}{l}\text { Emulsification of S/O suspension in } \\
\text { water phase }\end{array}$ & [41] \\
\hline \multirow{5}{*}{$\begin{array}{l}\text { Coherent } \\
\text { solids }\end{array}$} & Solder metal microparticles & $\begin{array}{l}\text { Solidification of liquid metal in } \\
\mathrm{M} / \mathrm{W} \text { or } \mathrm{M} / \mathrm{O} \text { emulsion }\end{array}$ & {$[42]$} \\
\hline & $\begin{array}{l}\text { Silica nano- or } \\
\text { microparticles }\end{array}$ & $\begin{array}{l}\text { Polymerisation of silicic acids by } \\
\text { interfacial or internal reaction }\end{array}$ & {$[13,43]$} \\
\hline & \multirow{2}{*}{ Solid lipid microspheres } & $\begin{array}{l}\text { Solidification of oil droplets in } \mathrm{O} / \mathrm{W} \\
\text { emulsion }\end{array}$ & [44] \\
\hline & & $\begin{array}{l}\text { Solvent evaporation from oil phase } \\
\text { in } \mathrm{O} / \mathrm{W} \text { emulsion }\end{array}$ & {$[45]$} \\
\hline & Crystal products & $\begin{array}{l}\text { Solvent evaporation from oil } \\
\text { droplets in O/W emulsion }\end{array}$ & {$[46,47]$} \\
\hline \multirow{3}{*}{$\begin{array}{l}\text { Structured } \\
\text { solid lipid } \\
\text { microcarriers }\end{array}$} & W/O microcarrier & $\begin{array}{l}\text { Solidification of oil phase in } \mathrm{W} / \mathrm{O} / \mathrm{W} \\
\text { emulsion }\end{array}$ & {$[37]$} \\
\hline & $\mathrm{S} / \mathrm{O}$ microcarrier & Freeze-drying of $\mathrm{S} / \mathrm{O} / \mathrm{W}$ emulsion & {$[37]$} \\
\hline & Solid microcarrier & Freeze-drying of W/O/W emulsion & {$[37]$} \\
\hline $\begin{array}{l}\text { Gel } \\
\text { microbeads }\end{array}$ & $\begin{array}{l}\text { Gelatin, Ca-alginate or } \\
\text { pectin microbeads }\end{array}$ & $\begin{array}{l}\text { Gelation of water droplets in } \mathrm{W} / \mathrm{O} \\
\text { emulsion }\end{array}$ & {$[17,48-50]$} \\
\hline $\begin{array}{l}\text { Protein } \\
\text { microspheres }\end{array}$ & Albumin microspheres & $\begin{array}{l}\text { Heat or chemical denaturation of } \\
\text { protein in W/O emulsion }\end{array}$ & {$[51-53]$} \\
\hline \multirow{6}{*}{$\begin{array}{l}\text { Polymeric } \\
\text { microspheres }\end{array}$} & $\begin{array}{l}\text { PSt, P(St-co-DVB), P(St-Co- } \\
\text { MMA), PUU-VP, etc. }\end{array}$ & $\begin{array}{l}\text { Direct suspension polymerisation in } \\
\mathrm{O} / \mathrm{W} \text { emulsion }\end{array}$ & {$[54-57,15]$} \\
\hline & PSt-PAAm composite & $\begin{array}{l}\text { Direct suspension polymerisation in } \\
\mathrm{W} / \mathrm{O} / \mathrm{W} \text { emulsion }\end{array}$ & [58] \\
\hline & P(AAm-co-AA) hydrogel & $\begin{array}{l}\text { Direct suspension polymerisation in } \\
\text { W/O emulsion }\end{array}$ & [59] \\
\hline & $\begin{array}{l}\text { PMMA microspheres and } \\
\text { large P(St-co-DVB) spheres }\end{array}$ & $\begin{array}{l}\text { Two-stage suspension } \\
\text { polymerisation in } \mathrm{O} / \mathrm{W} \text { emulsion }\end{array}$ & {$[60,61]$} \\
\hline & $\begin{array}{l}\text { PUU, PSt-PMMA, } \\
\text { biodegradable PLA spheres }\end{array}$ & $\begin{array}{l}\text { Solvent evaporation from oil phase } \\
\text { in } \mathrm{O} / \mathrm{W} \text { emulsion }\end{array}$ & [62-65] \\
\hline & $\mathrm{TiO}_{2} / \mathrm{Fe}_{3} \mathrm{O}_{4}$ embedded & $\begin{array}{l}\text { Solvent evaporation from oil phase } \\
\text { in } \mathrm{S} / \mathrm{O} / \mathrm{W} \text { emulsion }\end{array}$ & [66-68] \\
\hline \multirow{3}{*}{$\begin{array}{l}\text { Polymeric } \\
\text { core-shell } \\
\text { microcapsules } \\
\text { and hollow } \\
\text { particles }\end{array}$} & $\begin{array}{l}\mathrm{P}(\mathrm{St}-\mathrm{co} \text {-DMAEMA) } \\
\text { microcapsules }\end{array}$ & $\begin{array}{l}\text { Suspension polymerisation in } \mathrm{O} / \mathrm{W} \\
\text { emulsion }\end{array}$ & [69] \\
\hline & $\begin{array}{l}\text { Termosensitive PNIPAAm- } \\
\text { grafted PA microcapsules }\end{array}$ & Interfacial polymerisation & {$[70,71]$} \\
\hline & $\begin{array}{l}\mathrm{P}(\mathrm{St}-\mathrm{co} \text {-DMAEMA) hollow } \\
\text { particles }\end{array}$ & $\begin{array}{l}\text { Suspension polymerisation in } \mathrm{O} / \mathrm{W} \\
\text { emulsion }\end{array}$ & {$[72-74]$} \\
\hline $\begin{array}{l}\text { Colloidal } \\
\text { assemblies }\end{array}$ & $\begin{array}{l}\text { Uniform assemblies of } \\
\text { polystyrene microbeads }\end{array}$ & $\begin{array}{l}\text { Removal of water from S/W/O } \\
\text { emulsion }\end{array}$ & [33] \\
\hline
\end{tabular}


Table 3: Some premix membrane emulsification investigations reported so far.

\begin{tabular}{|c|c|c|c|c|c|c|}
\hline $\begin{array}{l}\text { Membrane } \\
\text { material }\end{array}$ & System & $\begin{array}{c}\text { Mean } \\
\text { pore size, } \\
\mathbf{d}_{\mathrm{m}}(\mu \mathrm{m})\end{array}$ & $\begin{array}{l}\text { Product } \\
\text { emulsion }\end{array}$ & $\begin{array}{l}\text { Mean droplet } \\
\text { size and span }\end{array}$ & $\underset{\left(m^{3} m^{-2} h^{-1}\right)}{\text { Flux }}$ & Ref. \\
\hline Tubular SPG & Cross flow & 2.7 and 4.2 & $\mathrm{O} / \mathrm{W}$ & $\begin{array}{c}1.4-2.1 \mathrm{~d}_{\mathrm{m}}, \\
\operatorname{span}=0.4-0.62\end{array}$ & $0.03-3.5$ & [88] \\
\hline Flat PTFE & Dead end & 1.0 & $\begin{array}{c}\mathrm{O} / \mathrm{W} \text { and } \\
\mathrm{W} / \mathrm{O}\end{array}$ & $2-4.1 \mathrm{~d}_{\mathrm{m}}$ & Up to 9 & [19] \\
\hline Flat PTFE & $\begin{array}{l}\text { Dead end } \\
\text { with phase } \\
\text { inversion }\end{array}$ & 1.0 & $\begin{array}{c}\mathrm{O} / \mathrm{W} \text { and } \\
\mathrm{W} / \mathrm{O}\end{array}$ & $2.8-4.0 \mathrm{~d}_{\mathrm{m}}$ & $1-5.5$ & [20] \\
\hline Flat PTFE & $\begin{array}{c}\text { Dead end, } \\
\text { multipass } \\
(n=1-3)\end{array}$ & 1.0 & $\mathrm{O} / \mathrm{W}$ & $\begin{array}{c}1.2-2.6 d_{m} \\
\operatorname{span}=0.55-0.9\end{array}$ & $2-18$ & [22] \\
\hline $\begin{array}{l}\text { Flat cellulose } \\
\text { acetate }\end{array}$ & Dead end & $\begin{array}{c}0.2,0.45 \\
0.8 \text { and } 3.0\end{array}$ & $\mathrm{~W} / \mathrm{O} / \mathrm{W}$ & $1.0-3.5 \mathrm{~d}_{\mathrm{m}}$ & Not given & [27] \\
\hline $\begin{array}{c}\text { Flat } \\
\text { polycarbonate }\end{array}$ & $\begin{array}{l}\text { Dead end, } \\
\text { multipass } \\
(\mathrm{n}=1-18)\end{array}$ & $\begin{array}{c}0.33,0.38 \\
0.44,0.6 \\
\text { and } 1.0\end{array}$ & $\mathrm{O} / \mathrm{W}$ & $\begin{array}{c}\leq 1.6 d_{m} \text { for } \mathrm{n}> \\
12\end{array}$ & $0.2-0.6$ & [26] \\
\hline Tubular SPG & $\begin{array}{l}\text { Dead end } \\
\text { multipass } \\
(\mathrm{n}=3)\end{array}$ & 1.1 & $\mathrm{~S} / \mathrm{O} / \mathrm{W}$ & $0.9 \mathrm{~d}_{\mathrm{m}}$ & 1.6 & [41] \\
\hline Tubular SPG & $\begin{array}{c}\text { Dead end, } \\
\text { multipass } \\
(\mathrm{n}=1-5)\end{array}$ & 10.7 & $\mathrm{~W} / \mathrm{O} / \mathrm{W}$ & $\begin{array}{c}0.41-1.2 \mathrm{~d}_{\mathrm{m}} \\
\mathrm{span}=0.28-0.6\end{array}$ & $0.8-37$ & [92] \\
\hline
\end{tabular}


Table 4: Some case studies on using direct membrane emulsification for single emulsion productions published after 1999.

\begin{tabular}{|c|c|c|c|c|c|}
\hline \multicolumn{2}{|c|}{ M E M B R A N E } & \multicolumn{2}{|c|}{ P R O D U T } & \multicolumn{2}{|l|}{ E M U L S I O N } \\
\hline Material & $\begin{array}{l}\text { Mean pore } \\
\text { size }\end{array}$ & $\begin{array}{l}\text { Mean droplet } \\
\text { size }\end{array}$ & Туре & Formulation & Ref. \\
\hline $\begin{array}{l}\text { Hypothetical with } \\
\text { porosity less than } \\
1.2-1.5 \%\end{array}$ & $5 \mu \mathrm{m}$ & $33 \mu \mathrm{m}^{*}$ & $\mathrm{O} / \mathrm{W}$ & $\begin{array}{l}\text { Equilibrium interfacial } \\
\text { tension of } 30 \mathrm{mN} / \mathrm{m}\end{array}$ & [97] \\
\hline $\begin{array}{l}\text { Microengineered } \\
\text { silicone nitride } \\
\text { microsieve }\end{array}$ & $7 \mu \mathrm{m}$ & $52-250 \mu \mathrm{m}$ & $\mathrm{O} / \mathrm{W}$ & $\begin{array}{l}\text { oil phase: HD coloured with } \\
\text { Sudan red } \\
\text { water phase: water }+1 \% \\
\text { Tween } 20\end{array}$ & [7], [28] \\
\hline $\begin{array}{l}\text { Microengineered } \\
\text { silicone nitride } \\
\text { microsieve }\end{array}$ & $4.8 \mu \mathrm{m}$ & $34-100 \mu \mathrm{m}$ & $\mathrm{O} / \mathrm{W}$ & $\begin{array}{l}\text { oil phase: } \mathrm{HD} \\
\text { water phase: water }+0.1-10 \\
\% \text { Tween } 20\end{array}$ & [98] \\
\hline SPG & $1,10 \mu \mathrm{m}$ & $\begin{array}{c}6-10.9 \mu \mathrm{m} \\
\mathrm{CV}=11-23 \%\end{array}$ & $\mathrm{O} / \mathrm{W}$ & $\begin{array}{l}\text { oil phase: } \mathrm{HD}+\mathrm{St}+\mathrm{DVB} \\
\text { water phase: } \text { water }+ \text { PVA + } \\
\text { SLS }\end{array}$ & [99] \\
\hline SPG & $\begin{array}{c}1,2.1,3.2 \\
\mu \mathrm{m}\end{array}$ & $3-300 \mu \mathrm{m}$ & $\mathrm{O} / \mathrm{W}$ & $\begin{array}{l}\text { oil phase: HD or soybean oil } \\
\text { water phase: water }+0.02-2 \\
\% \text { Tween } 20 \text { or } 0.01-3 \% \text { Na- } \\
\text { CAS or } 1 \% \text { BLG or mixed } \\
\text { oil phase: suflower oil }\end{array}$ & {$[100]$} \\
\hline $\begin{array}{l}\text { Coated } \alpha \text {-alumina } \\
\text { and zirconia }\end{array}$ & $\begin{array}{c}0.1,0.5 \\
\mu \mathrm{m}\end{array}$ & $0.5-12 \mu \mathrm{m}$ & $\mathrm{O} / \mathrm{W}$ & $\begin{array}{l}\text { water phase: } \text { water }+1 \% \\
\text { SDS or } 0.02-0.5 \% \beta- \\
\text { CAS/11S soya globulin }\end{array}$ & {$[12]$} \\
\hline $\begin{array}{l}\text { Sol-gel porous } \\
\text { glass (sol-gel PG) }\end{array}$ & $0.6 \mu \mathrm{m}$ & $3 \mu \mathrm{m}$ & $\mathrm{W} / \mathrm{O}$ & $\begin{array}{l}\text { oil phase: } \mathrm{Tl}+\text { Span } 20 \\
\text { water phase: aqueous } \\
\text { colloidal silica Snowtex } \mathrm{N}\end{array}$ & {$[14]$} \\
\hline $\begin{array}{l}\text { Polypropylene } \\
\text { hollow fibers }\end{array}$ & $0.4 \mu \mathrm{m}$ & $\begin{array}{c}0.25-1.9 \mu \mathrm{m} \\
\operatorname{span}=1.1-2.1\end{array}$ & $\mathrm{~W} / \mathrm{O}$ & $\begin{array}{l}\text { oil phase: mineral oil Velocite } \\
\text { no. } 3+2.5-10 \% \text { PGPG } 90 \\
\text { water phase: demineralized } \\
\text { water }\end{array}$ & [18] \\
\hline Polycarbonate & $10 \mu \mathrm{m}$ & $\begin{array}{c}20-150 \mu \mathrm{m} \\
\mathrm{CV}=20-50 \%\end{array}$ & $\mathrm{O} / \mathrm{W}$ & $\begin{array}{l}\text { oil phase: pure soybean oil or } \\
\text { soybean oil }+2 \% \text { TOMAC } \\
\text { water phase: water }+0.3 \text { wt. } \% \\
\text { SDS or } 1 \% \text { PGFE or } 1 \% \\
\text { Tween } 20\end{array}$ & {$[25]$} \\
\hline $\begin{array}{l}\text { Polyamide hollow } \\
\text { fibers }\end{array}$ & $10 \mathrm{~nm}$ & $\begin{array}{l}1.87 \mu \mathrm{m} \\
\mathrm{CV}=33 \%\end{array}$ & $\mathrm{O} / \mathrm{W}$ & $\begin{array}{l}\text { oil phase: pure IO or IO + } \\
\text { naproxen methyl ester } \\
\text { water phase: phosphate buffer } \\
\text { pH } 7.00+0.1-0.2 \% \text { SDS + } \\
0.4-0.8 \% \text { PVA }\end{array}$ & {$[8]$} \\
\hline $\begin{array}{l}\text { Straight-through } \\
\text { silicon } \\
\text { microchannels }\end{array}$ & $17 \mu \mathrm{m}$ & $\begin{array}{c}39-170 \mu \mathrm{m}^{* *} \\
\mathrm{CV}=2.5-40 \% \\
\text { for SDS and } \\
\text { Tween } 20\end{array}$ & $\mathrm{O} / \mathrm{W}$ & $\begin{array}{l}\text { oil phase: pure soybean oil or } \\
\text { soybean oil }+2 \% \text { TOMAC } \\
\text { water phase: water }+1 \text { wt. } \% \\
\text { SDS or } 1 \% \text { CTMABr or } 1 \% \\
\text { Tween } 20\end{array}$ & [30] \\
\hline
\end{tabular}

*The value calculated using computational fluid dynamics (CFD).

${ }^{* *}$ The value at the upper limit was obtained in the "continuous outflow" zone. 
Table 5: Some investigations on one-stage suspension polymerisation in $\mathrm{O} / \mathrm{W}$ emulsion prepared by membrane emulsification *

\begin{tabular}{|c|c|c|c|}
\hline Polymer & Emulsion formulation & Membrane and product & Ref. \\
\hline $\begin{array}{l}\text { Polystyrene } \\
\text { (PSt) }\end{array}$ & $\begin{array}{l}\text { DP: St, Hp, and BPO } \\
\frac{\mathrm{CP}}{\mathrm{NaNO}_{2}}\end{array}$ & $\begin{array}{l}\text { Membrane: } 1.0,1.4 \text {, and } 2.9 \mu \mathrm{m} \text { SPG } \\
\text { Droplets: } \mathrm{d}_{\mathrm{e}}=6-21 \mu \mathrm{m}, \mathrm{CV}_{\mathrm{e}}=5-20 \% \\
\text { Spheres: } \mathrm{d}_{\mathrm{s}}=8-12 \mu \mathrm{m}, \mathrm{CV}_{\mathrm{s}}=9-16 \%\end{array}$ & [54] \\
\hline PASt & $\begin{array}{l}\text { DP: Xl/DD mixture, ASt, DVB, } \\
\text { and BPO } \\
\text { CP: Doubly distilled water, } \\
\text { SDS, PVA, and } \mathrm{Na}_{2} \mathrm{SO}_{4}\end{array}$ & $\begin{array}{l}\text { Membrane: } 1 \mu \mathrm{m} \text { SPG } \\
\text { Droplets: Not given } \\
\text { Spheres: } \mathrm{d}_{\mathrm{s}}=3-5 \mu \mathrm{m}\end{array}$ & [113] \\
\hline $\mathrm{P}(\mathrm{St}-\mathrm{co}-\mathrm{DVB})$ & $\begin{array}{l}\text { DP: 4-MP, St, DVB, and PSt } \\
\underline{\text { CP: }} \text { Water, PVA, and } \mathrm{NaCl}\end{array}$ & $\begin{array}{l}\text { Membrane: Stainless steel with } 100 \text { and } \\
150 \mu \mathrm{m} \text { laser drilled pores } \\
\text { Droplets: } \mathrm{d}_{\mathrm{e}}=100-300 \mu \mathrm{m} \\
\text { Spheres: } \mathrm{d}_{\mathrm{s}}=124 \mu \mathrm{m}\end{array}$ & [15] \\
\hline $\begin{array}{l}\mathrm{P}(\mathrm{St}-\mathrm{co}-\mathrm{DVB}) \\
\text { particles with } \\
\text { toner additives }\end{array}$ & $\begin{array}{l}\text { DP: St, DVB, E-81, SPBS, } \\
\text { ADVN, and AIBN } \\
\text { CP: Water, SDS, and PVA }\end{array}$ & $\begin{array}{l}\text { Membrane: } 1.0,2.0 \text {, and } 3.0 \mu \mathrm{m} \text { SPG } \\
\text { Droplets: } \mathrm{d}_{\mathrm{e}}=2-7.3 \mu \mathrm{m} \\
\text { Spheres: } \mathrm{d}_{\mathrm{s}}=1.9-6.1 \mu \mathrm{m}\end{array}$ & [78] \\
\hline $\begin{array}{l}\text { Carbon black } \\
\text { embedded P(St- } \\
\text { co-BA) }\end{array}$ & $\begin{array}{l}\text { DP: St, BA, Carbon black } \\
\text { particles, Span 60, and BPO } \\
\text { CP: Water, SLS, and PVA }\end{array}$ & $\begin{array}{l}\text { Membrane: } 2.9 \mu \mathrm{m} \text { SPG } \\
\text { Droplets: Not given } \\
\text { Spheres: } \mathrm{d}_{\mathrm{s}}=5.8 \mu \mathrm{m}, \mathrm{CV}_{\mathrm{s}}=11 \%\end{array}$ & [115] \\
\hline $\mathrm{P}(\mathrm{St}-c o-\mathrm{MMA})$ & $\begin{array}{l}\text { DP: St, DVB, MMA, EGDMA, } \\
\mathrm{HD} \text {, and BPO } \\
\text { CP: Water, PVA, SLS, } \mathrm{Na}_{2} \mathrm{SO}_{4} \text {, } \\
\text { and HQ }\end{array}$ & $\begin{array}{l}\text { Membrane: } 1.4 \mu \mathrm{m} \text { SPG } \\
\text { Droplets: } \mathrm{d}_{\mathrm{e}}=9-16 \mu \mathrm{m}, \mathrm{CV}_{\mathrm{e}}=12-16 \% \\
\text { Spheres: } \mathrm{d}_{\mathrm{s}}=7-14 \mu \mathrm{m}, \mathrm{CV}_{\mathrm{s}}=13-28 \%\end{array}$ & {$[56]$} \\
\hline $\begin{array}{l}\text { DOP plasticized } \\
\mathrm{P}(\text { St-co-MA), } \\
\mathrm{P}(\mathrm{MMA}-\mathrm{co}- \\
\mathrm{MA}) \text {, and } \mathrm{P}(\mathrm{St}- \\
\text { co-BMA) }\end{array}$ & $\begin{array}{l}\text { DP: St, MMA, MA, BMA, BA, } \\
\text { BMA, DOP, and BPO or } \\
\text { ADVN } \\
\text { CP: Water, PVA, SDS, } \mathrm{Na}_{2} \mathrm{SO}_{4} \text {, } \\
\text { and } \mathrm{NaNO}_{2} \text { or PDA }\end{array}$ & $\begin{array}{l}\text { Membrane: } 0.5 \text { and } 0.9 \mu \mathrm{m} \text { SPG } \\
\text { Droplets: } \mathrm{d}_{\mathrm{e}}=4-9 \mu \mathrm{m}, \mathrm{CV}_{\mathrm{e}}=8-40 \% \\
\text { Spheres: } \mathrm{d}_{\mathrm{s}}=3-7 \mu \mathrm{m}, \mathrm{CV}_{\mathrm{s}}=10-27 \%\end{array}$ & [119] \\
\hline $\begin{array}{l}\text { P(butadiene-co- } \\
\text { styrene) }\end{array}$ & $\begin{array}{l}\text { DP: Tl, BR, St, DVB, CA, and } \\
\text { BPO } \\
\text { CP: Water and SLS }\end{array}$ & $\begin{array}{l}\text { Membrane: } 1.6 \mu \mathrm{m} \text { SPG } \\
\text { Droplets: Not given } \\
\text { Spheres: } d_{s}=4.5-5.2 \mu \mathrm{m}, \mathrm{CV}_{\mathrm{s}}=9-16 \%\end{array}$ & [120] \\
\hline $\begin{array}{c}\text { P(St-co- } \\
\text { DMAEMA })\end{array}$ & $\begin{array}{l}\overline{\mathrm{DP}}: \text { HD, St, DMAEMA, and } \\
\text { ADVN } \\
\text { CP: Water with PVP or PVA, } \\
\text { SLS, and HQ, DAP or } \mathrm{NaNO}_{2}\end{array}$ & $\begin{array}{l}\text { Membrane: } 1.4 \mu \mathrm{m} \text { SPG } \\
\text { Droplets: Not given } \\
\text { Spheres: } \mathrm{d}_{\mathrm{s}}=5-11 \mu \mathrm{m}, \mathrm{CV}_{\mathrm{s}}=10-15 \%\end{array}$ & [74] \\
\hline $\begin{array}{l}\text { P(St- co-DVB- } \\
\text { co-TMPTMA) } \\
\text { containing PIP }\end{array}$ & $\begin{array}{l}\text { DP: St, DVB, BANI-M, 4-MP, } \\
\text { TMPTMA, and ADVN } \\
\text { CP: Water, PVA, SLS, } \mathrm{NaNO}_{2} \text {, } \\
\text { and } \mathrm{Na}_{2} \mathrm{SO}_{4}\end{array}$ & $\begin{array}{l}\text { Membrane: } 1.4 \mu \mathrm{m} \mathrm{SPG} \\
\text { Droplets: Not given } \\
\text { Spheres: } \mathrm{d}_{\mathrm{s}}=8-14 \mu \mathrm{m}, \mathrm{CV}_{\mathrm{s}}=11-42 \%\end{array}$ & [117] \\
\hline P(meth)acrylate & $\begin{array}{l}\text { DP: Tl and/or Hp, ADVN, MP } \\
\text { and various combinations of 2- } \\
\text { EHA, 2-EHMA, EGDMA, } \\
\text { MMA, LA, LMA, and CHA } \\
\text { CP: water, PVA, SLS, and } \\
\mathrm{NaNO}_{2}\end{array}$ & $\begin{array}{l}\text { Membrane: 0.9, 5.2, and } 9.2 \mu \mathrm{m} \text { SPG } \\
\text { Droplets: } \mathrm{d}_{\mathrm{e}}=28-37 \mu \mathrm{m}, \mathrm{CV}_{\mathrm{e}}=10-40 \% \\
\text { (using } 5.2 \mu \mathrm{m} \text { SPG) } \\
\text { Spheres: } \mathrm{d}_{\mathrm{s}}=5-45 \mu \mathrm{m}, \mathrm{CV}_{\mathrm{s}}=10-17 \% \\
\text { (using } 0.9-9.2 \mu \mathrm{m} \text { SPG) }\end{array}$ & [121] \\
\hline $\begin{array}{l}\text { PUU-VP, PUU- } \\
\text { P(St-co- } \\
\text { EGDMA), } \\
\text { PUU-P(St-co- } \\
\text { TMPTMA) }\end{array}$ & $\begin{array}{l}\text { DP: Xl, PU prepolymer, VP or } \\
\text { St and EGDMA or TMPTMA, } \\
\text { and ADVN } \\
\frac{\mathrm{CP}}{\mathrm{Na}_{2} \mathrm{SO}_{4} \text {, and SLS }}\end{array}$ & $\begin{array}{l}\text { Membrane: } 5.2 \mu \mathrm{m} \text { SPG } \\
\text { Droplets: Not given } \\
\text { Spheres: } \mathrm{d}_{\mathrm{s}}=15-21 \mu \mathrm{m}, \mathrm{CV}_{\mathrm{s}}=9-18 \%\end{array}$ & [57] \\
\hline
\end{tabular}


Table 6: Investigations on direct (one-stage) suspension polymerisation in $\mathrm{W} / \mathrm{O}$ and $\mathrm{W} / \mathrm{O} / \mathrm{W}$ emulsions prepared by SPG membrane emulsification.

\begin{tabular}{|c|c|c|c|}
\hline Polymer & Emulsion formulation & Membrane and product & Ref. \\
\hline $\begin{array}{l}\text { Composite } \\
\text { PSt-PAAm }\end{array}$ & $\begin{array}{l}\text { W/O/W emulsion: } \\
\text { Internal water phase: water, } \\
\text { AAm, MBAAm, and KPS } \\
\text { Oil phase: } \mathrm{St} \text {, DVB or EGDMA, } \\
\text { ADVN, Span 85, and PSt } \\
\text { External water phase: water, } \\
\text { PVP, } \mathrm{SLS}, \mathrm{Na}_{2} \mathrm{SO}_{4}, \mathrm{HQ} \text {, and } \\
\mathrm{NaNO}_{2} \text { or } \mathrm{DAP}\end{array}$ & $\begin{array}{l}\text { Membrane: } 5.2 \mu \mathrm{m} \text { SPG } \\
\text { Droplets: } \mathrm{d}_{\mathrm{e}}=20-22 \mu \mathrm{m}, \mathrm{CV}_{\mathrm{e}}=7-11 \% \\
\text { Spheres: } \mathrm{d}_{\mathrm{s}}=15-22 \mu \mathrm{m}, \mathrm{CV}_{\mathrm{s}}=8-40 \%\end{array}$ & [58] \\
\hline $\begin{array}{l}\text { P(AAm-co-AA) } \\
\text { and PAAm } \\
\text { hydrogel }\end{array}$ & $\begin{array}{l}\text { W/O emulsion: } \\
\text { Disperse phase.: AAm, (AA), } \\
\text { MBAAm, TMEDA, and NaCl } \\
\text { Continuous phase: CHx, AIBN, } \\
\text { and SUNSOFT818H }\end{array}$ & $\begin{array}{l}\text { Membrane: } 0.33,0.73,1.1 \text { and } 1.7 \mu \mathrm{m} \\
\text { hydrophobic SPG } \\
\text { Droplets: Not given } \\
\text { Spheres: } \mathrm{d}_{\mathrm{s}}=1.4-7.4 \mu \mathrm{m} \text {, Span }=0.35- \\
0.98\end{array}$ & $\begin{array}{l}{[59,} \\
123]\end{array}$ \\
\hline
\end{tabular}

Table 7: Investigations on direct suspension polymerisation in $\mathrm{O} / \mathrm{W}$ emulsions produced by microfabricated channel devices.

\begin{tabular}{|c|c|c|c|}
\hline Polymer & Emulsion formulation & Device and product & Ref. \\
\hline PDVB & $\begin{array}{l}\text { Disperse phase: DVB with } 2 \\
\text { \% BPO } \\
\frac{\text { Continuous phase: Water with }}{0.2 \% \text { SDS }}\end{array}$ & $\begin{array}{l}\text { Silicon MCs: } 30 \mu \mathrm{m} \text { MC width, } 16 \mu \mathrm{m} \\
\text { MC depth, } 98 \text { and } 240 \mu \mathrm{m} \text { terrace length } \\
\text { Droplets: } \mathrm{d}_{\mathrm{e}}=75 \text { and } 90 \mu \mathrm{m}, \mathrm{CV}_{\mathrm{e}}=2.8 \text { and } \\
2.3 \% \\
\text { Spheres: } \mathrm{d}_{\mathrm{s}}=69 \text { and } 87 \mu \mathrm{m}, \mathrm{CV}_{\mathrm{s}}=4.1 \text { and } \\
4.8 \%\end{array}$ & [124] \\
\hline PDVB & $\begin{array}{l}\text { Disperse phase: DVB with } 2 \\
\text { \% BPO } \\
\frac{\text { Continuous phase: Water with }}{0.1-0.2 \% \text { SDS }}\end{array}$ & $\begin{array}{l}\text { Silicon MCs: } 3-12 \mu \mathrm{m} \text { MC width, } 1-2 \mu \mathrm{m} \\
\text { MC depth, } 98 \text { and } 5-25 \mu \mathrm{m} \text { terrace length } \\
\text { Droplets: } \mathrm{d}_{\mathrm{e}}=4 \text { and } 10 \mu \mathrm{m}, \mathrm{CV}_{\mathrm{e}}=4.4 \text { and } \\
9.1 \% \text { (for } 0.2 \% \text { SDS solution) } \\
\text { Spheres: } \mathrm{d}_{\mathrm{s}}=3 \text { and } 9 \mu \mathrm{m}, \mathrm{CV}_{\mathrm{s}}=6 \text { and } 7 \%\end{array}$ & [125] \\
\hline Poly(HDDA) & $\begin{array}{l}\text { Disperse phase: HDDA with } 1 \\
\text { wt. \% DAROCUR }{ }^{\circledR} 1173 \\
\frac{\text { Continuous phase: Water with }}{2 \% \text { PVA }}\end{array}$ & $\begin{array}{l}\text { Quartz glass microfluidic device with a T- } \\
\text { junction: monomer channel } 120 \times 30 \mu \mathrm{m}, \\
\text { aqueous phase channel } 220 \times 30 \mu \mathrm{m} . \\
\text { Droplets: } \mathrm{d}_{\mathrm{e}}=30-120 \mu \mathrm{m}, \mathrm{CV}_{\mathrm{e}}=1-2 \% \\
\text { Spheres: } \mathrm{d}_{\mathrm{s}}=30-120 \mu \mathrm{m}, \mathrm{CV}_{\mathrm{s}}=1-2 \%\end{array}$ & [32] \\
\hline $\begin{array}{c}\text { Bichromal } \\
\text { poly(IBOA) }\end{array}$ & $\begin{array}{l}\text { Disperse phase: IBOA with } 2 \\
\text { \% initiator and } 10 \% \text { carbon } \\
\text { black (for black monomer) or } \\
\mathrm{TiO}_{2} \text { (for white monomer) } \\
\text { Continuous phase: Water with } \\
2 \% \text { PVA }\end{array}$ & $\begin{array}{l}\text { Quartz glass microfluidic device with a Y- } \\
\text { junction and two coflowing channels: } \\
\text { feed channels } 120 \times 100 \mu \mathrm{m} \text {, outlet channel } \\
220 \times 100 \mu \mathrm{m} \text {. } \\
\text { Droplets: } \mathrm{d}_{\mathrm{e}}=90-190 \mu \mathrm{m}, \mathrm{CV}_{\mathrm{e}}=0.3-0.7 \% \\
\text { Spheres: } \mathrm{d}_{\mathrm{s}}=90-190 \mu \mathrm{m}, \mathrm{CV}_{\mathrm{s}}=0.3-0.7 \%\end{array}$ & [32] \\
\hline
\end{tabular}


Table 8: Investigations on droplet swelling method (two-stage suspension polymerisation) for production of polymer microspheres. The primary (seed) emulsion was prepared by SPG membrane emulsification.

\begin{tabular}{|c|c|c|c|}
\hline Polymer & Formulation & Membrane and Product & Ref. \\
\hline $\begin{array}{l}\text { Poly(methyl } \\
\text { methacrylate) }\end{array}$ & $\begin{array}{l}\text { Primary O/W emulsion: } \\
\text { DP: Bz, Hp, HD, and BPO } \\
\mathrm{CP}: \text { Water, PVA, SLS, and } \\
\mathrm{NaNO}_{2} \\
\text { Secondary O/W emulsion: } \\
\text { MMA (and EGDMA) in aqueous } \\
\text { SLS solution }\end{array}$ & $\begin{array}{l}\text { Membrane: } 0.5 \mu \mathrm{m} \text { SPG } \\
\text { Seed droplets: } d_{\mathrm{e}}=2-9 \mu \mathrm{m}, \mathrm{CV}_{\mathrm{e}}= \\
10-11 \% \\
\text { Polymer spheres: } \mathrm{d}_{\mathrm{s}}=2.4-37 \mu \mathrm{m}, \\
\mathrm{CV}_{\mathrm{s}}=9-15 \%\end{array}$ & [60] \\
\hline $\begin{array}{l}\text { Poly(styrene-co- } \\
\text { divinylbenzene) }\end{array}$ & $\begin{array}{l}\text { Primary O/W emulsion: } \\
\text { DP: Different mixtures of DVB, } \\
\text { St, HD, LA, Hp, and BPO } \\
\text { CP: Water, PVA, SLS, }\left(\mathrm{Na}_{2} \mathrm{SO}_{4}\right. \\
\text { and DHBSP) } \\
\text { Secondary O/W emulsion: } \\
\text { Various mixtures of St, DVB, } \\
\text { GMA, HA, AA, IA, Bz, DCB, } \\
\text { TCB in aqueous SLS solution }\end{array}$ & $\begin{array}{l}\text { Membrane: } 5.2 \mu \mathrm{m} \text { SPG } \\
\text { Seed droplets: } \mathrm{d}_{\mathrm{e}}=26-36 \mu \mathrm{m}, \mathrm{CV}_{\mathrm{e}}= \\
\text { 8.6-38\% } \\
\text { Swollen droplets: } \mathrm{d}_{\mathrm{e}}=32-111 \mu \mathrm{m} \text {, } \\
\mathrm{CV}_{\mathrm{e}}=8.3-55 \% \\
\text { Polymer spheres: } \mathrm{d}_{\mathrm{s}}=32-102 \mu \mathrm{m} \text {, } \\
\mathrm{CV}_{\mathrm{s}}=7.9-28 \%\end{array}$ & [61] \\
\hline $\begin{array}{l}\text { Composite PSt- } \\
\text { PMMA with } \\
\text { higher content of } \\
\text { HEMA }\end{array}$ & $\begin{array}{l}\text { Primary O/W emulsion: } \\
\text { DP: Different mixtures of St, } \\
\text { DVB, HD, Bz, and BPO } \\
\text { CP: Water, PVA, SLS, } \mathrm{Na}_{2} \mathrm{SO}_{4} \text {, } \\
\text { and HQ. } \\
\text { Secondary } \mathrm{O} / \mathrm{W} \text { emulsion: } \\
\text { St, HEMA or MMA, HEMA, } \\
\text { EGDMA (and HA) in aqueous } \\
\text { solution of SLS (and } \mathrm{NaNO}_{2} \text { ) }\end{array}$ & $\begin{array}{l}\text { Membrane: SPG, pore size not given } \\
\text { Swollen droplets: swelling ratio was } \\
\text { 1.6-8 } \\
\text { Polymer spheres: } \mathrm{d}_{\mathrm{s}}=8-18 \mu \mathrm{m}, \mathrm{CV}_{\mathrm{s}} \\
=9.1-15.5 \%\end{array}$ & [129] \\
\hline $\begin{array}{l}\text { Polymers } \\
\text { including PIP }\end{array}$ & $\begin{array}{l}\text { Primary O/W emulsion: } \\
\text { DP: Different mixtures of BANI- } \\
\text { M, St, BA, 2-EHA, and LA } \\
\text { CP: Water, PVA, and SLS } \\
\text { Secondary O/W emulsion: } \\
\text { MMA, MA, EGDMA, HA, OA, } \\
\text { and IA in aqueous SLS solution }\end{array}$ & $\begin{array}{l}\text { Membrane: } 1.4 \mu \mathrm{m} \text { SPG } \\
\text { Swollen droplets: } \mathrm{d}_{\mathrm{e}}=8 \mu \mathrm{m}, \mathrm{CV}_{\mathrm{e}}= \\
11.7 \% \\
\text { Polymer spheres: } \mathrm{d}_{\mathrm{s}}=6 \mu \mathrm{m}, \mathrm{CV}_{\mathrm{s}}= \\
10.6 \% \text { (for the given swollen } \\
\text { droplets) }\end{array}$ & [117] \\
\hline $\begin{array}{l}\text { P(St-co- } \\
\text { PEGMMA) and } \\
\text { PEGPMMA }\end{array}$ & $\begin{array}{l}\text { Primary O/W emulsion: } \\
\text { DP: t-BPP, (St), and Bz } \\
\text { CP: Water, PVA, and SDS } \\
\text { Secondary O/W emulsion: } \\
\text { PEGMMA, EGDMA, Bz, Bac, } \\
\text { EA, and BuOH in aqueous } \\
\text { solution of PVA and SDS }\end{array}$ & $\begin{array}{l}\text { Membrane: } 9 \mu \mathrm{m} \text { SPG } \\
\text { Seed droplets: } \mathrm{d}_{\mathrm{e}}=29.6 \mu \mathrm{m} \\
\text { Swollen droplets: } \mathrm{d}_{\mathrm{e}}=60.8 \mu \mathrm{m} \\
\text { Polymer spheres: } \mathrm{d}_{\mathrm{s}}=50.0 \mu \mathrm{m}, \mathrm{CV}_{\mathrm{s}} \\
=7.64 \%\end{array}$ & [112] \\
\hline
\end{tabular}


Table 9: Some recent investigations on preparation of polymer microspheres and microcapsules by membrane emulsification and subsequent organic solvent evaporation.

\begin{tabular}{|c|c|c|c|}
\hline Microcapsule & Formulation & Membrane and Product & Ref. \\
\hline $\begin{array}{l}\mathrm{Fe}_{3} \mathrm{O}_{4} \text { embedded } \\
\mathrm{P}(\mathrm{St}-\mathrm{co}-\mathrm{AA}) \text {, } \\
\mathrm{P}(\mathrm{St}-\mathrm{Co}-\mathrm{BA}) \text {, and } \\
\text { SBR }\end{array}$ & 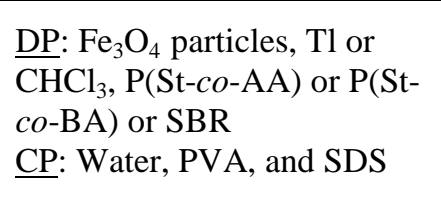 & $\begin{array}{l}\text { Membrane: 1.4, 5.2, and } 9.5 \mu \mathrm{m} \text { SPG } \\
\mathrm{Fe}_{3} \mathrm{O}_{4} \text { in Tl: } \mathrm{d}_{\mathrm{e}}=6-75 \mu \mathrm{m}, \mathrm{CV}_{\mathrm{e}}=11-27 \\
\% ; \mathrm{d}_{\mathrm{s}}=5-39 \mu \mathrm{m}, \mathrm{CV}_{\mathrm{s}}=14-50 \% \\
\mathrm{Fe}_{3} \mathrm{O}_{4} \text { in } \mathrm{CHCl}_{3}: \mathrm{d}_{\mathrm{e}}=8-30 \mu \mathrm{m}, \mathrm{CV}_{\mathrm{e}}= \\
21-94 \% ; \mathrm{d}_{\mathrm{s}}=7-25 \mu \mathrm{m}, \mathrm{CV}_{\mathrm{s}}=24-101 \%\end{array}$ & [68] \\
\hline $\begin{array}{l}\text { PLA } \\
\text { biodegradable }\end{array}$ & $\begin{array}{l}\text { DP: DCM, PLA, and HD or } \\
\text { LOH } \\
\text { CP: Water, PVA, and SLS }\end{array}$ & $\begin{array}{l}\text { Membrane: } 5.2 \mu \mathrm{m} \text { SPG } \\
\text { Droplets: } \mathrm{d}_{\mathrm{e}}=14-38 \mu \mathrm{m}, \mathrm{CV}_{\mathrm{e}}=11-35 \% \\
\text { Spheres: } \mathrm{d}_{\mathrm{s}}=9-24 \mu \mathrm{m} \mathrm{CV} \mathrm{s}_{\mathrm{s}}=12-31 \%\end{array}$ & {$[65]$} \\
\hline $\begin{array}{l}\text { PSt-PMMA } \\
\text { composite }\end{array}$ & $\begin{array}{l}\text { DP: DCM, PMMA, PSt, and } \\
\text { LOH } \\
\text { CP: Water, PVA, and SLS }\end{array}$ & $\begin{array}{l}\text { Membrane: } 5.2 \mu \mathrm{m} \text { SPG } \\
\text { Droplets: } \mathrm{d}_{\mathrm{e}}=11-30 \mu \mathrm{m}, \mathrm{CV}_{\mathrm{e}}=13-17 \% \\
\text { Spheres: } \mathrm{d}_{\mathrm{s}} \approx 10 \mu \mathrm{m}\end{array}$ & [64] \\
\hline $\begin{array}{l}\mathrm{TiO}_{2} \text { embedded } \\
\mathrm{P}(\mathrm{St}-\mathrm{Co}-\mathrm{AA}) \\
\mathrm{P}(\mathrm{St}-\mathrm{Co}-2-\mathrm{EHA}) \\
\text { and } \mathrm{P}(\mathrm{St}-\mathrm{co}- \\
\text { DMAEMA) }\end{array}$ & $\begin{array}{l}\text { DP: Tl, ML, HD, HA, } \mathrm{TiO}_{2} \\
\text { powder, Disperbyk-111 or } \\
\text { 180, P(St-co-AA) or P(St- } \\
\text { co-2-EHA) or P(St-co- } \\
\text { DMAEMA) } \\
\text { CP: Water, PVA, and SDS }\end{array}$ & $\begin{array}{l}\text { Membrane: } 1.4,2.8,5.2,7.0 \text { and } 9.5 \mu \mathrm{m} \\
\text { SPG } \\
\text { Droplets: } \mathrm{d}_{\mathrm{e}}=13-23 \mu \mathrm{m} \\
\text { Spheres: } \mathrm{d}_{\mathrm{s}}=2-20 \mu \mathrm{m}, \mathrm{CV}_{\mathrm{s}}=30-66 \%\end{array}$ & {$[66,67]$} \\
\hline PUU & $\begin{array}{l}\text { DP: Xl and PU prepolymers } \\
\text { CP: Water, PVP or MST-1, } \\
\text { PVA, and SLS }\end{array}$ & $\begin{array}{l}\text { Membrane: } 5.2 \mu \mathrm{m} \text { SPG } \\
\text { Droplets: } \mathrm{d}_{\mathrm{e}}=7-30 \mu \mathrm{m}, \mathrm{CV}_{\mathrm{e}}=10 \% \\
\text { Spheres: } \mathrm{d}_{\mathrm{s}}=5-20 \mu \mathrm{m}, \mathrm{CV}_{\mathrm{s}}=8 \%\end{array}$ & {$[62]$} \\
\hline
\end{tabular}




\section{Figure captions}

Figure 1: Some products of membrane and microchannel emulsification.

Figure 2: Flowsheet for manufacture of some particulates via membrane emulsification routes.

Figure 3: Schematic diagram of membrane emulsification methods.

Figure 4: Membrane emulsification systems for controlling hydrodynamic conditions near the membrane surface.

Figure 5: Evolution of hexadecyl palmitate in a cross flow membrane crystallization (XMC) process.

Figure 6: Flowsheet for manufacture of three kinds of solid lipid microcarriers for nutrient or drug controlled release using SPG membrane emulsification. The dashed area represents the temperature-controlled operations at $80{ }^{\circ} \mathrm{C}$ (above a melting point of oil).

Figure 7: The SEM photographs of a W/O solid lipid microcarrier for oral administration of anticancer drug irinotecan hydrochloride (CPT-11). The microcarrier was prepared by a temperature-controlled SPG membrane emulsification, followed by cooling and filtration of solidified W/O/W emulsion. Reproduced with permission from ref. [105]. 
Figure 8: Polydivinylbenzene microspheres, made by Sekisui Chemical Industries Co. Ltd. as spacers for LCD devices, prepared by membrane emulsification and subsequent suspension polymerisation. Reproduced with permission from ref. [34].

Figure 9: Polymer beads made by interfacial polymerisation using a perforated spinning stainless steel membrane.

Figure 10: General flowsheet for manufacture of polymer microspheres by two-stage suspension polymerisation incorporating membrane emulsification.

Figure 11: Schematic illustration of the preparation route and the controlled release behavior of the thermoresponsive microcapsule: (a) oil droplet; (b) core-shell microcapsule with a porous shell; (c) hollow particle with a porous shell; (d) hollow particle with PNIPAAm gates; (e) loading an active agent into the microcapsule; (f) active agent-loaded microcapsule; and (g) releasing the active agent from the microcapsule. Reproduced with permission from ref. [71]. 


\section{Figures}

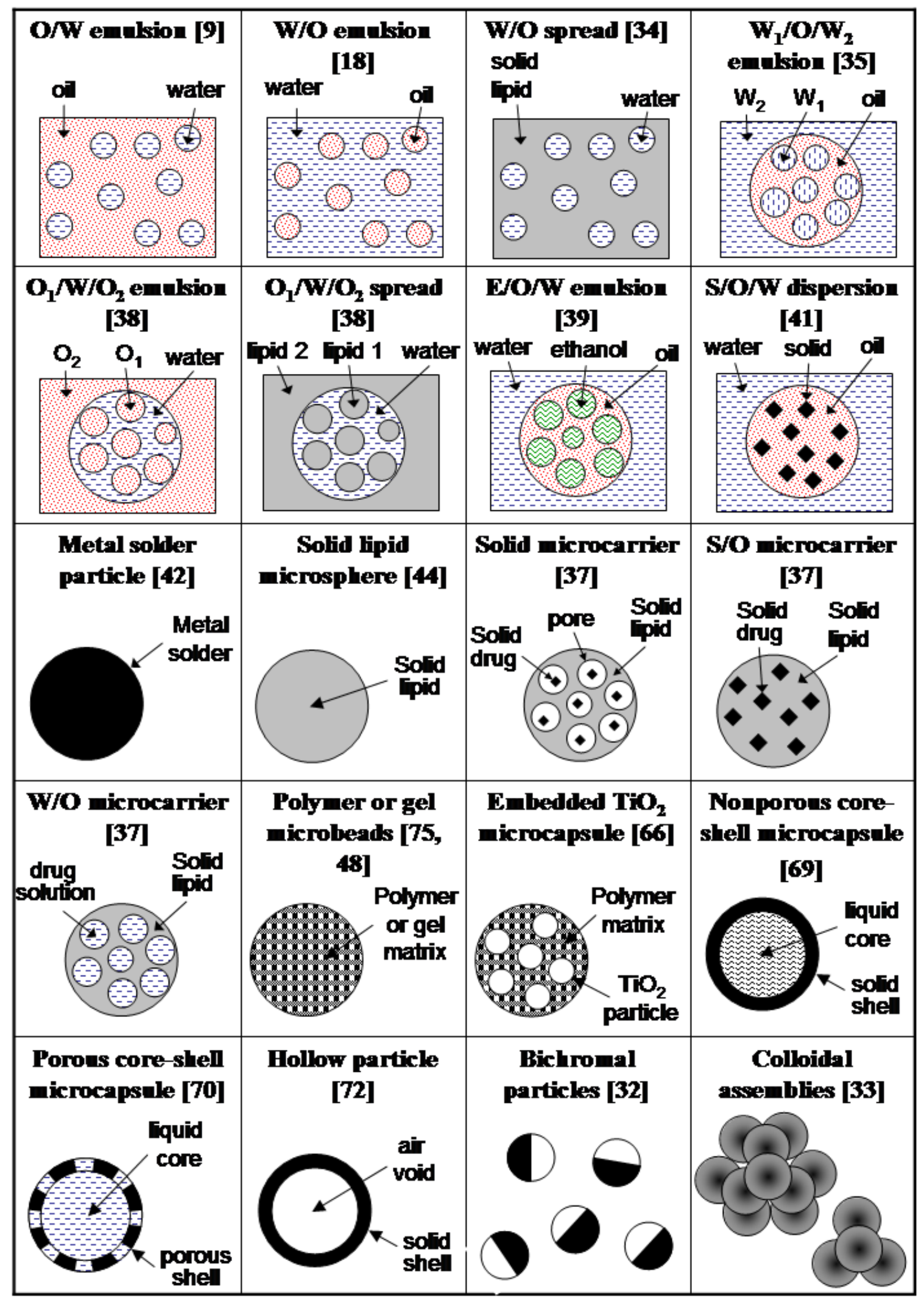

Figure 1 


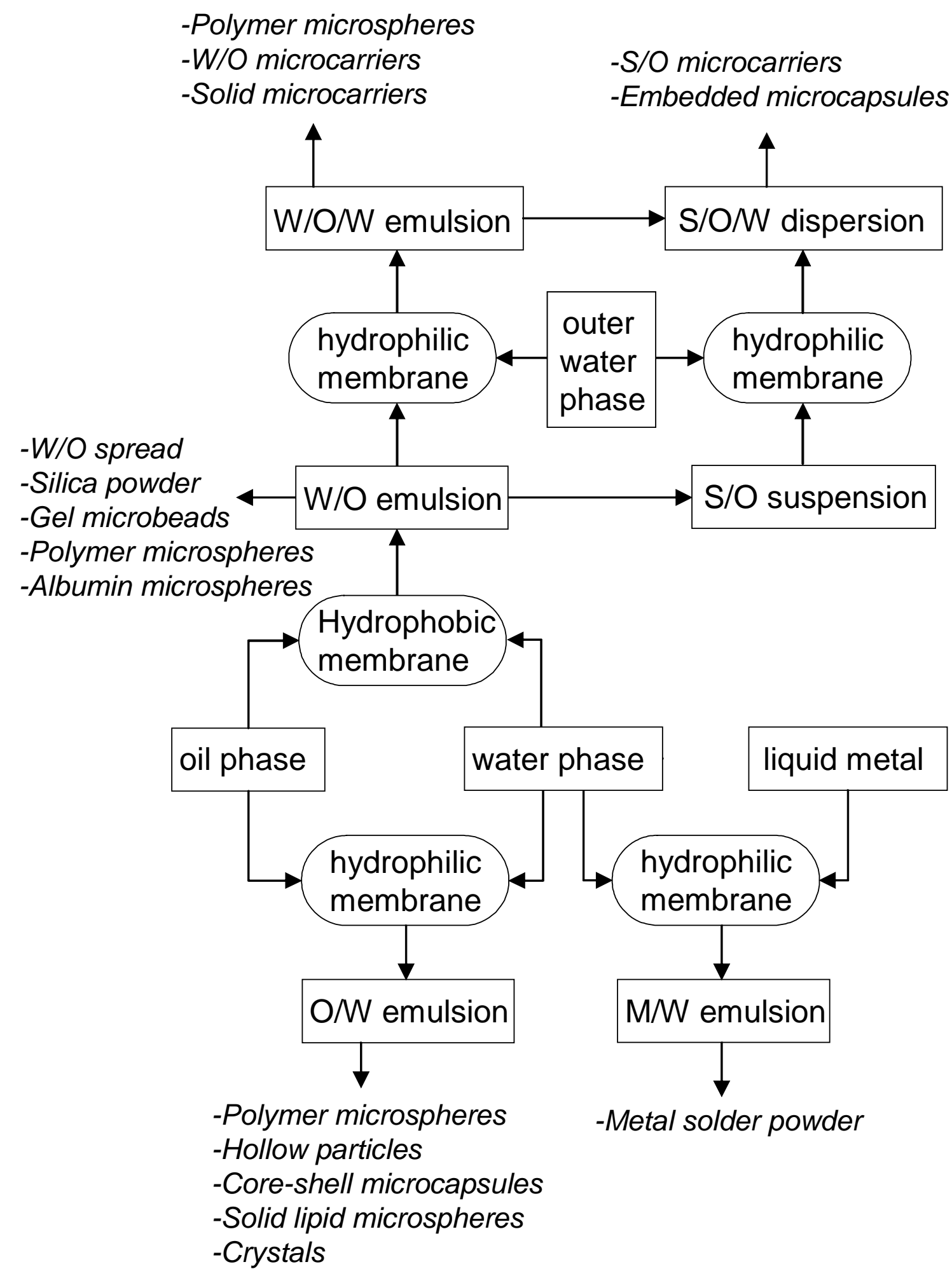

Figure 2 


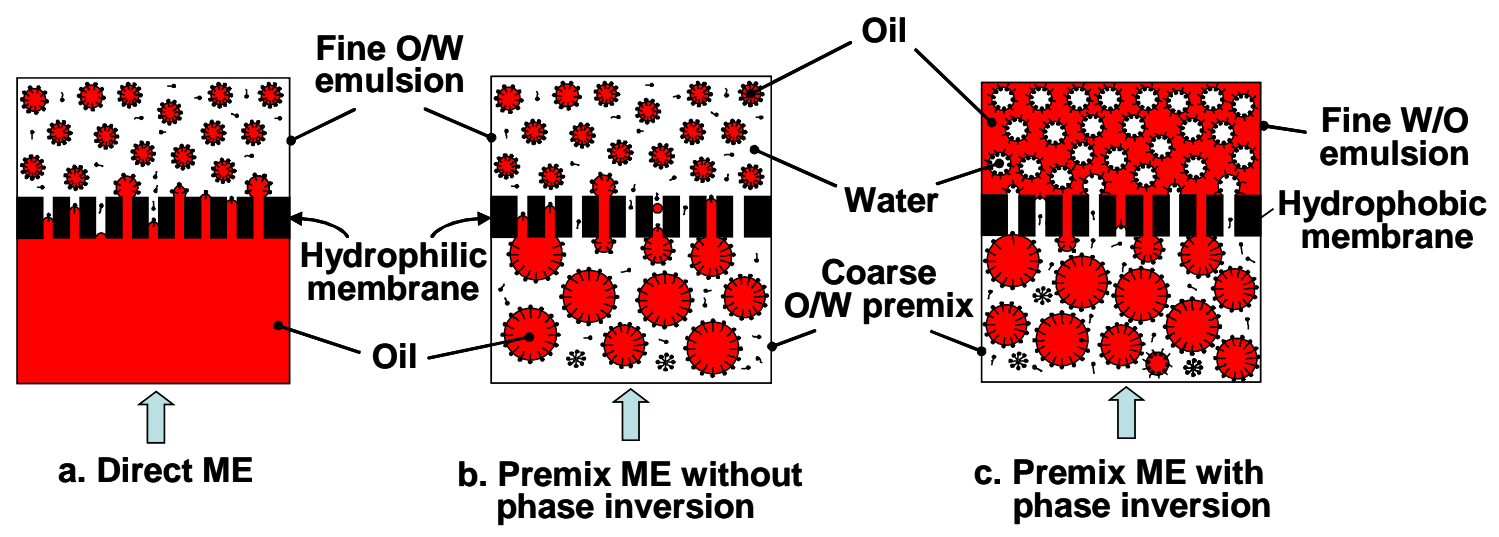

Figure 3

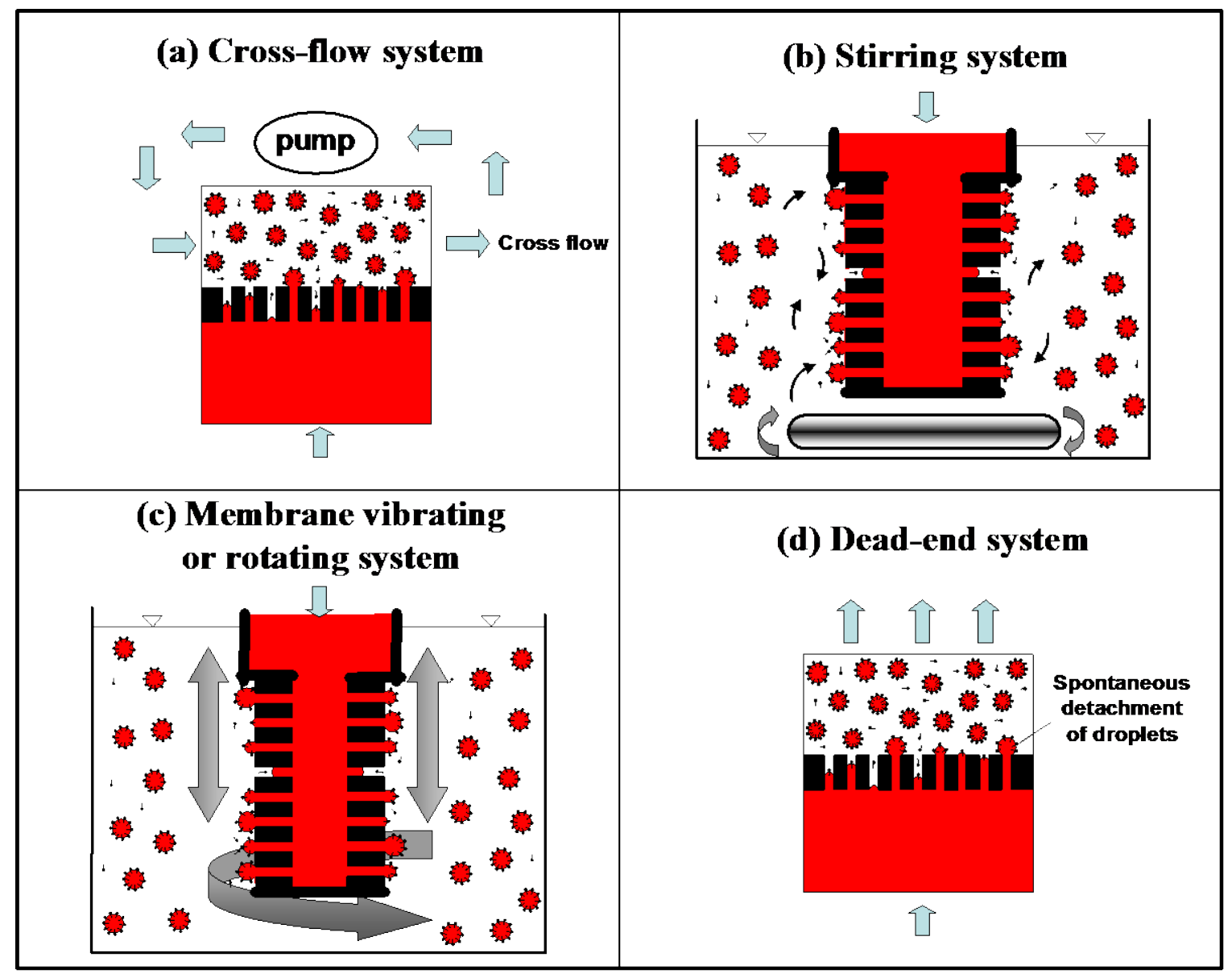

Figure 4 


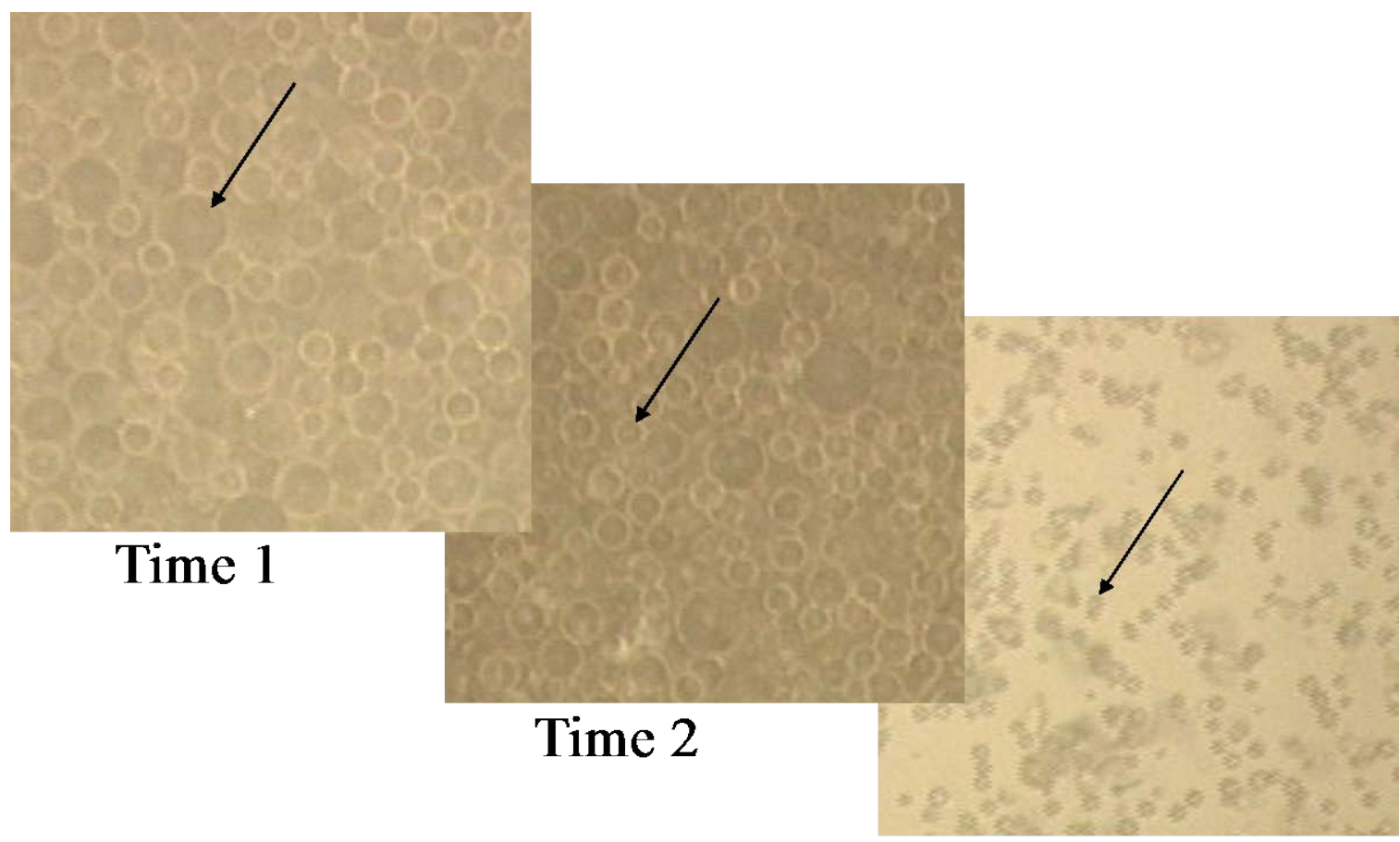

Time 3

Figure 5 


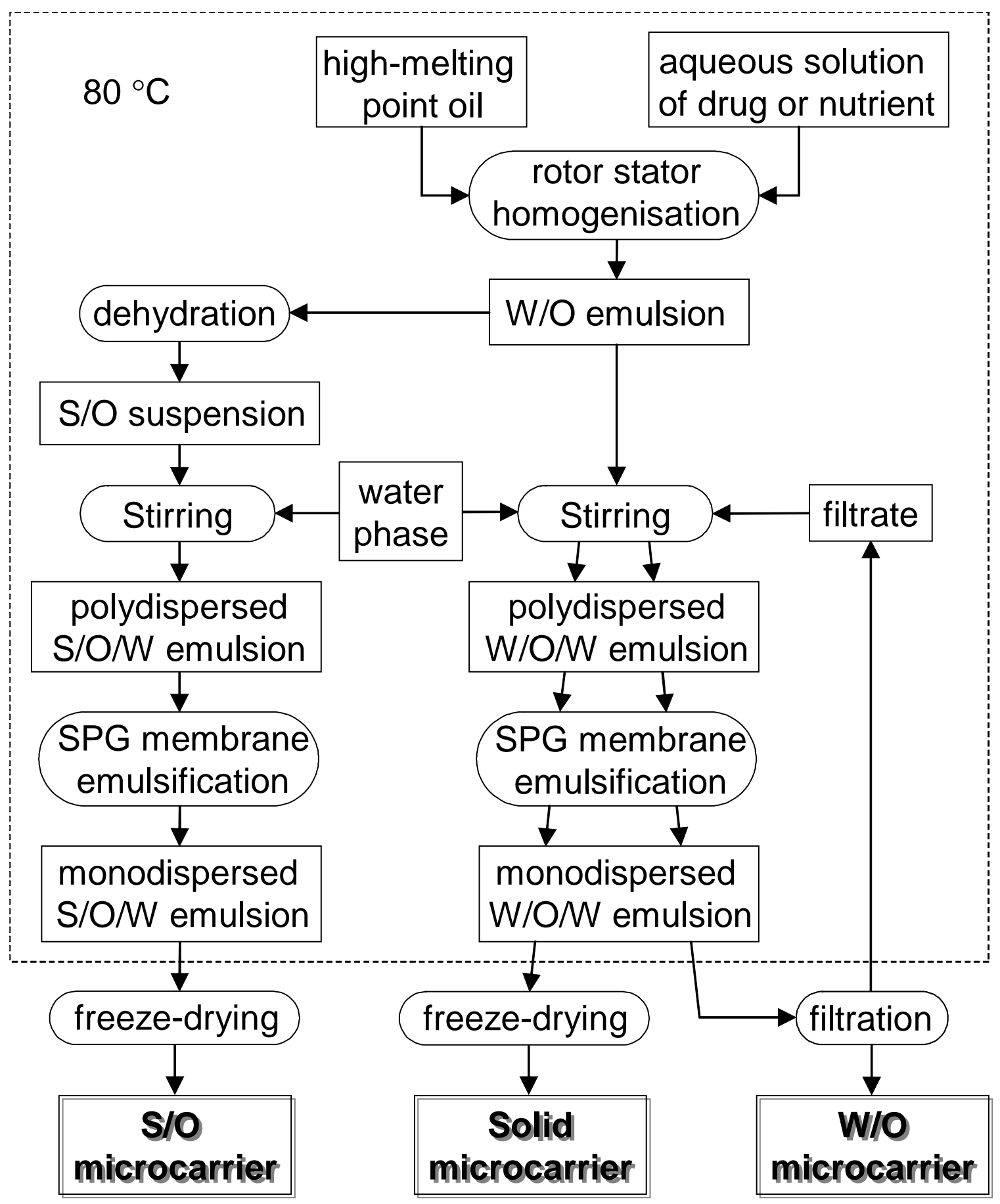

Figure 6 


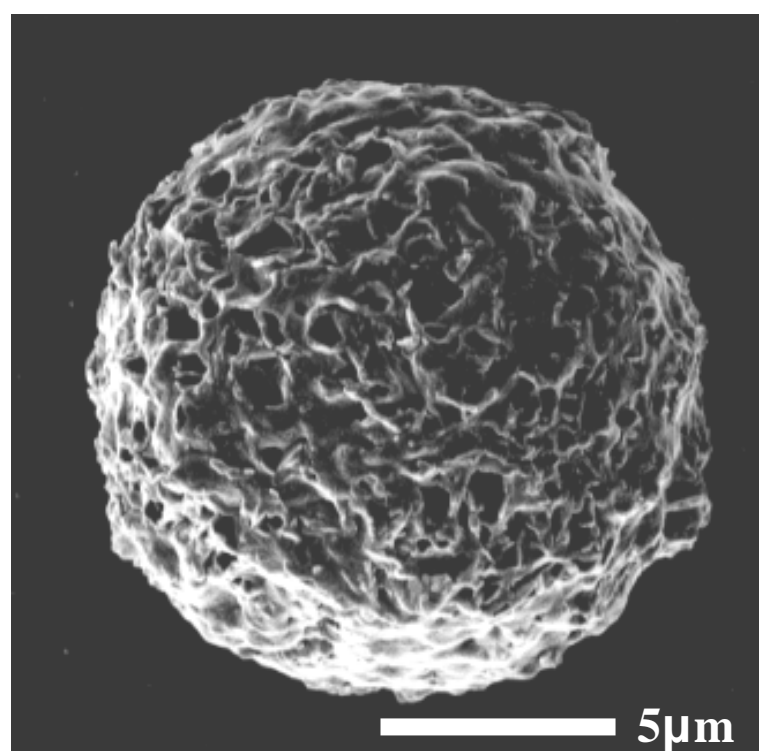

a) Outer surface

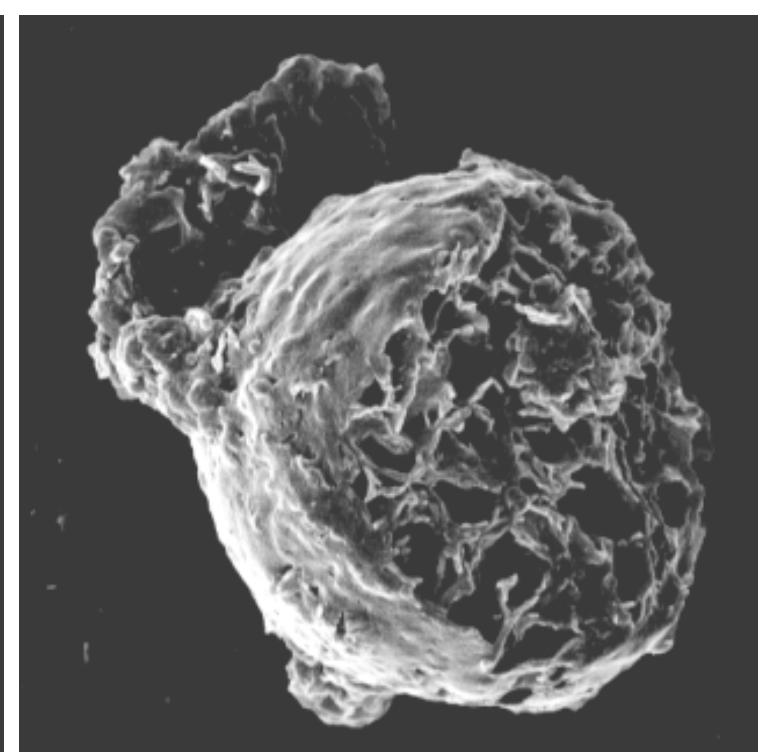

b) Cross section

Figure 7 


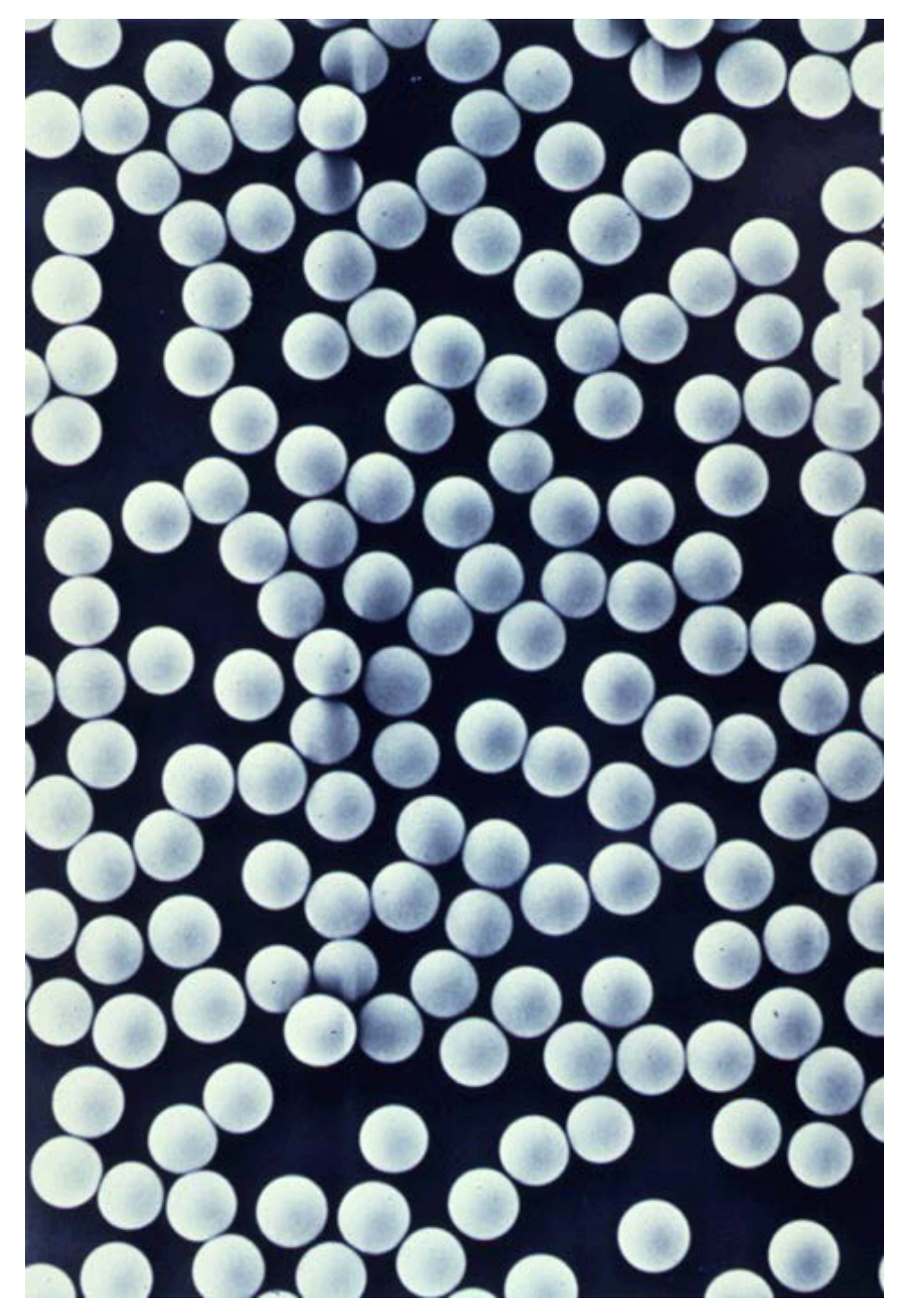

Figure 8 


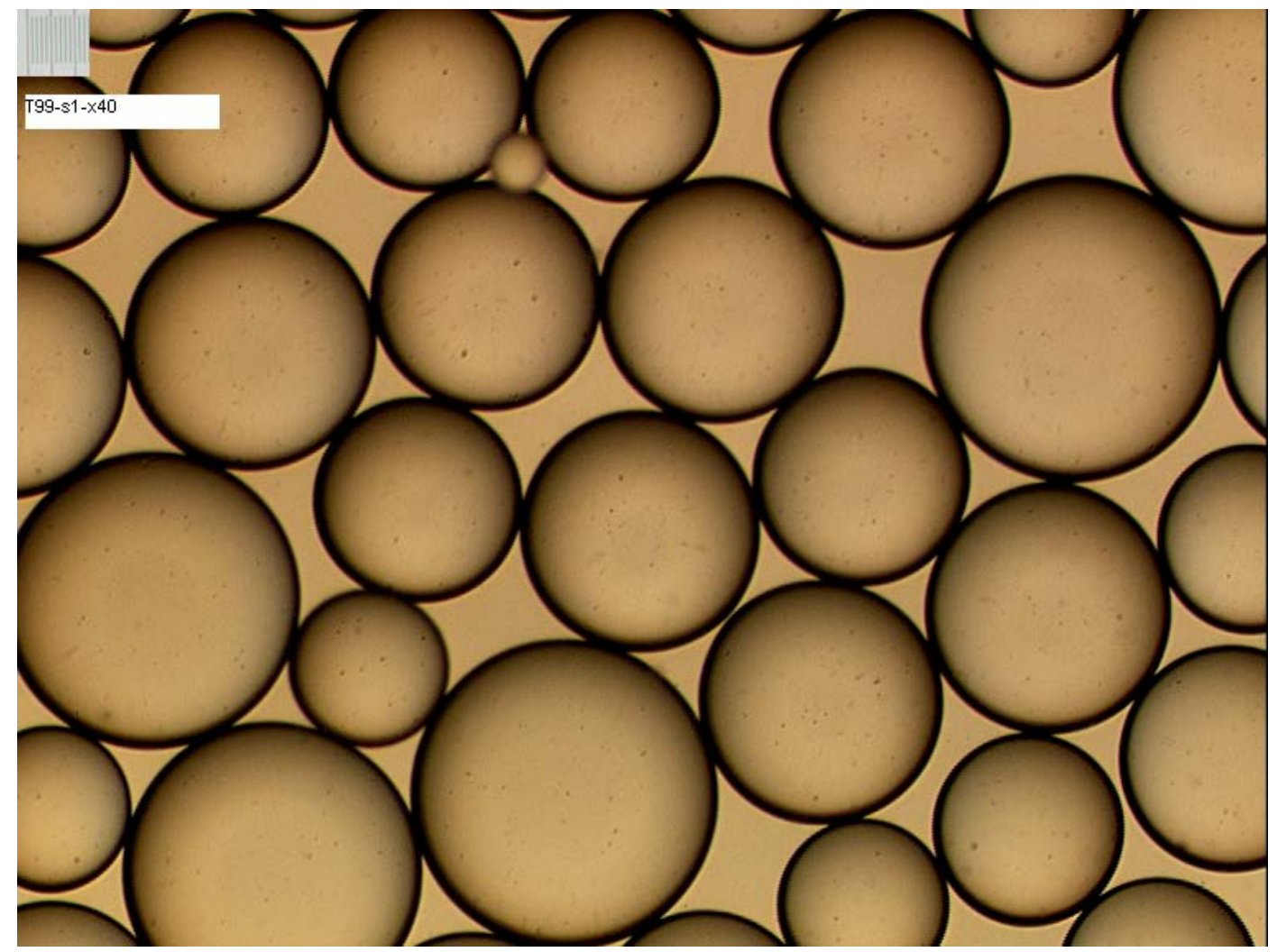

Figure 9 


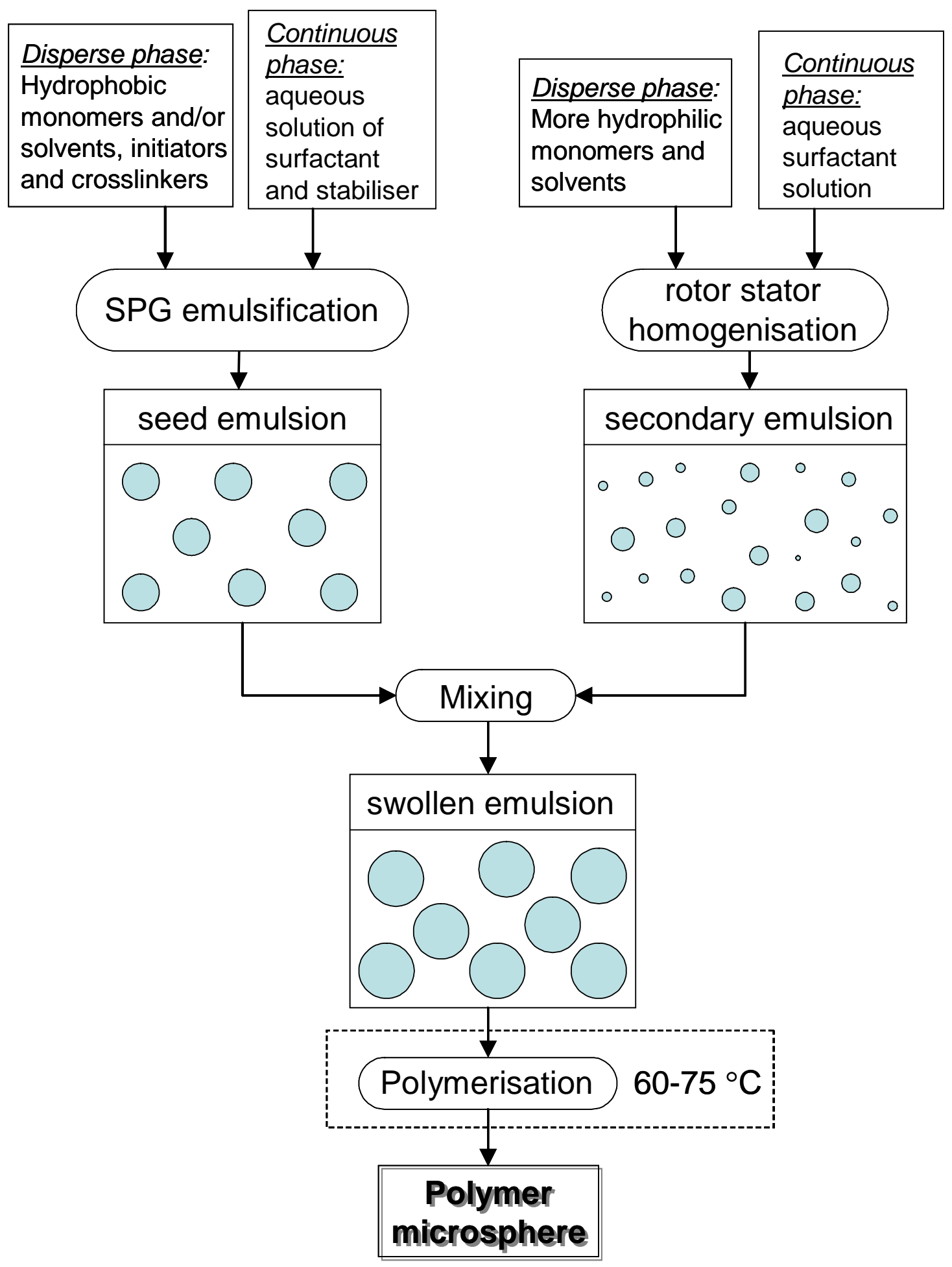

Figure 10 


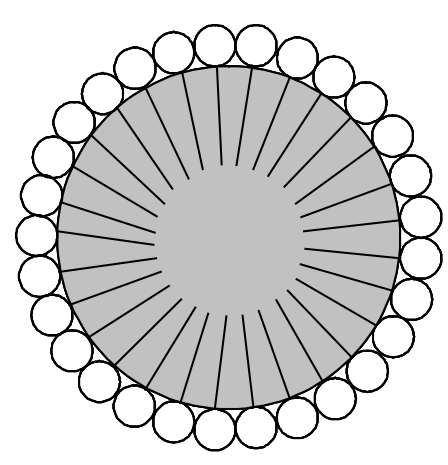

(a)
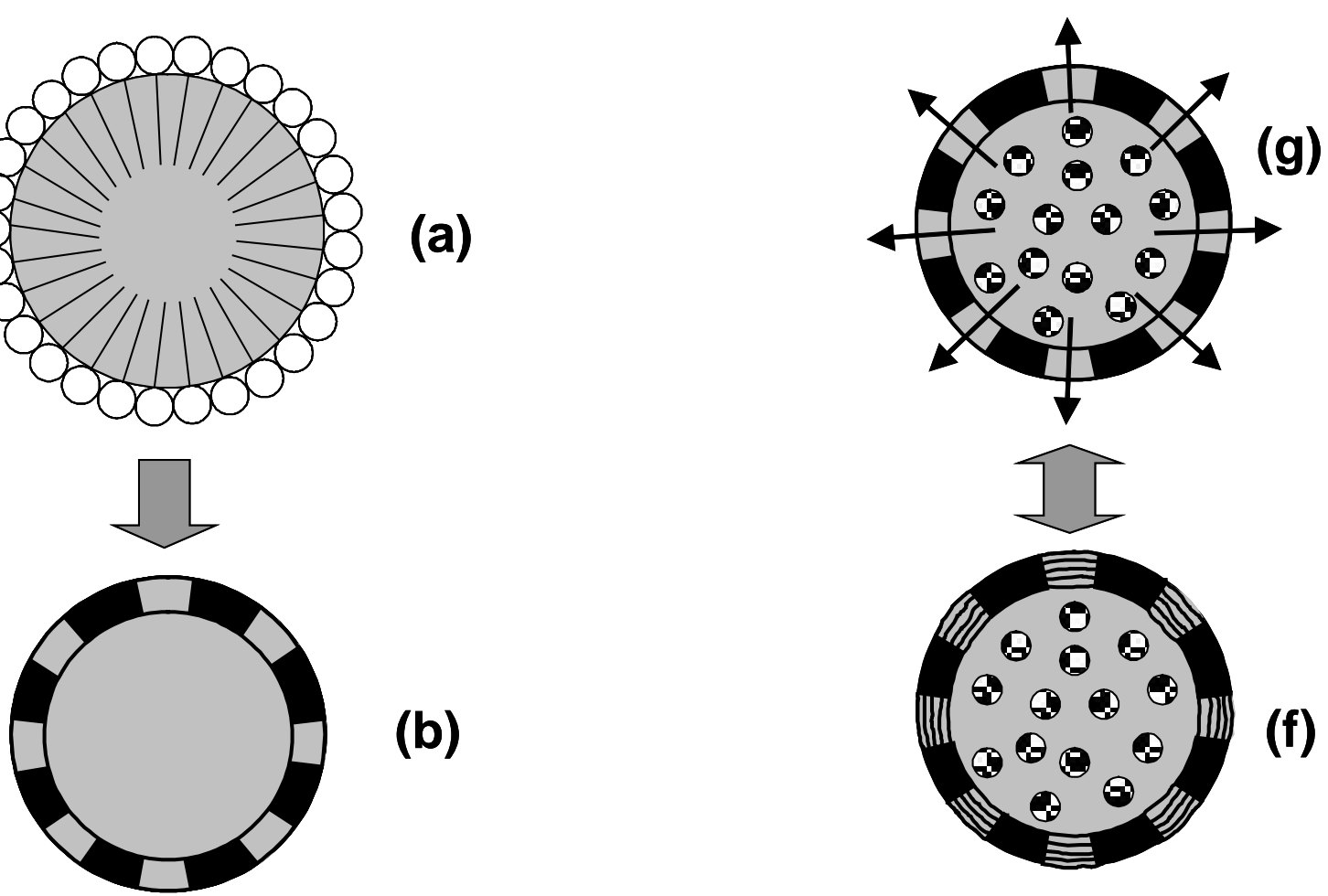

(b)

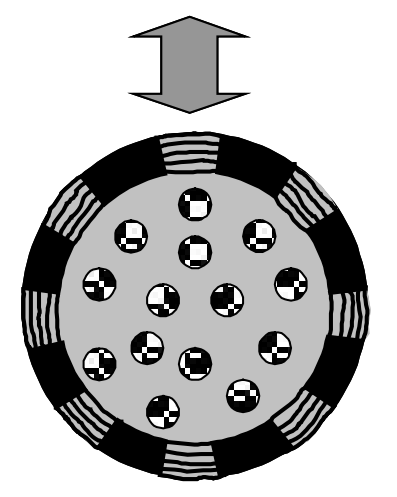

(f)

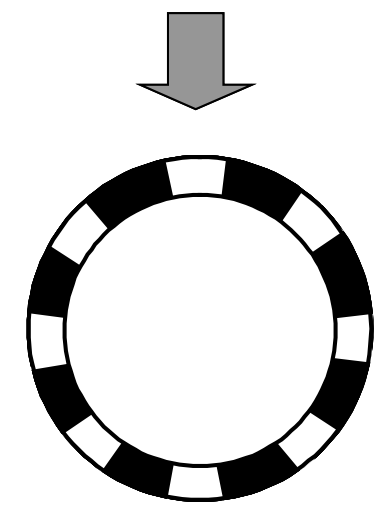

(c)
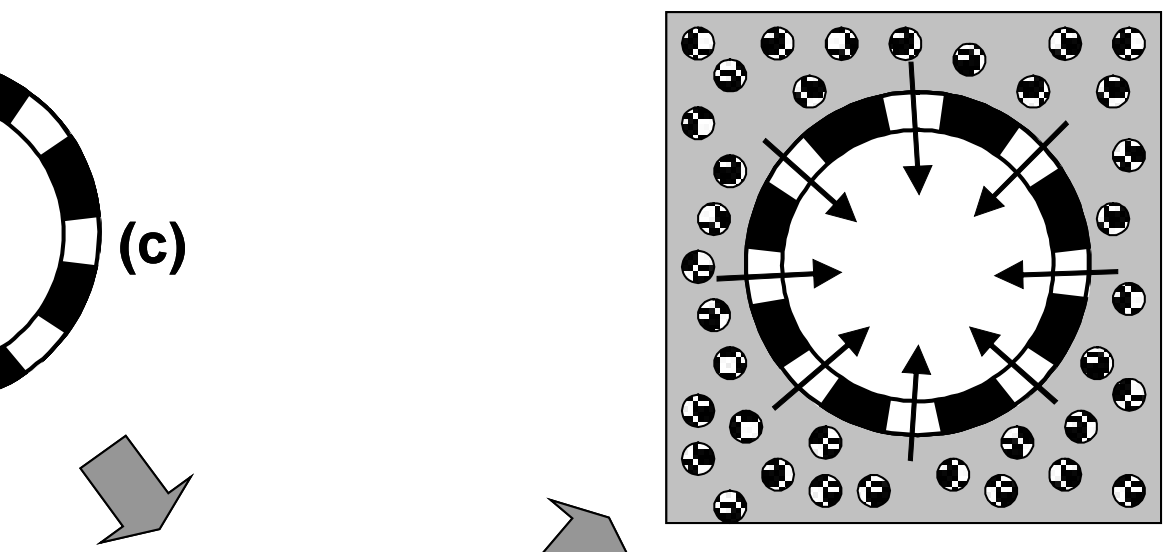

(d)

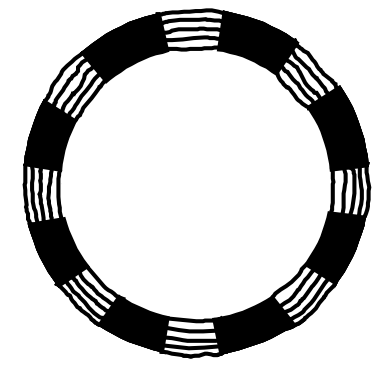

(e)

Figure 11 